\title{
"E foi proclamada a escravidão": Stanislaw Ponte Preta e a representação satírica do golpe militar
}

Dislane Zerbinatti Moraes USP

\section{RESUMO}

O assunto deste ensaio é a crônica humorística de Stanislaw Ponte Preta, heterônimo de Sérgio Porto, publicada em livros entre os anos de 1964 e 1968 . O gênero predominante é o satírico e para estudá-lo efetuamos a análise de procedimentos e figuras de linguagem dos textos: paródia, estilização, metáfora, ironia e efeitos de comicidade. Primeiramente analisamos o ponto de vista do narrador e depois apresentamos um quadro das representações humorísticas dos militares, funcionários públicos, trabalhadores e membros dos poderes Executivo e Legislativo.

Palavras-chave: Stanislaw Ponte Preta; Golpe militar de 1964; Crônica humorística.

\section{ABSTRACT}

The subject of this paper is the humorous chronicle of Stanislaw Ponte Preta, heteronym of Sérgio Porto, published as book from 1964 to 1968 . The main literary genre is the satirical one, and in order to study it, we analyzed the procedures and figures of speech of the texts: parody, stylization, metaphor, irony and comical affects. First we analyzed the point of view of the narrator and after we presented a framework of the humorous representations of the military, public employees, workers and government members and other politicians. Keywords: Stanislaw Ponte Preta; Military coup of 1964; Humorous chronicle. 
Doutor Equinócio ainda não passou por aqui. Se chegar será recebido como amigo, com foguetes, passeatas e festas. Febeapá 1

O que é bom para os EUA é bom para o Brasil. (Juracy Magalhães) Febeapá 2

Este ensaio trata das manifestações humorísticas de tom satírico presentes na imprensa carioca da década de 1960, isto é, aquelas que visavam atingir os agentes sociais envolvidos na elaboração do golpe militar de 1964. Stanislaw Ponte Preta, persona humorística criada pelo jornalista e escritor Sérgio Porto, tomou para si a incumbência de construir uma imagem de ridicularização dos eventos políticos do período. As crônicas publicadas no jornal Última Hora tiveram grande repercussão entre os leitores e se transformaram em um corpus de noções, imagens, sentimentos e discursos representativos dos grupos de oposição aos militares. ${ }^{1}$

O estudo procura mapear esse corpus de representações elaboradas pela esquerda brasileira, considerando-o como uma dimensão do imaginário social, um espaço discursivo e de interpretação que favoreceu, ou pelo menos, moldou a compreensão dos acontecimentos no momento em que foram vividos. Ainda hoje, por que não dizer, é referência, como registro documental do "espírito" de uma época, para todos que se interessam por esse período da história política e cultural brasileira. Quem não se lembra, ou já não ouviu falar, do Febeapá - Festival de besteira que assola o país, como imagem simbólica do período da ditadura militar; ou do Samba do crioulo doido, retrato afetivo das camadas pobres, marginalizadas, tentando assimilar os discursos dominantes? E, como esquecer Tia Zulmira, personagem que representava a racionalidade, a coerência, a inteligência - num período em que isso era moeda rara - , dizendo que estávamos "caindo no perigoso terreno da galhofa”, quando pensávamos nas peripécias das autoridades militares para se justificarem como representantes legítimos do Estado brasileiro? Por fim, Stanislaw nos legou uma imagem poderosa, iluminada, colorida e sintética do significado do golpe militar de 1964, ao acionar os recursos humorísticos da surpresa, da inversão de expectativa e da condensação de idéias, na frase "E foi proclamada a escravidão". ${ }^{2}$ 


\section{O CONTEXTO DE PRODUÇÃO E RECEPÇÃO \\ Das CRÔNICAS de Stanislaw Ponte Preta}

Sérgio Porto era carioca de nascimento. Iniciou sua carreira jornalística como crítico de cinema no Jornal do Povo, de propriedade do Barão de Itararé (Aparício Torelly). Foi cronista esportivo e repórter policial. A personagem que marcou sua carreira, Stanislaw Ponte Preta, foi criada quando escrevia para o Diário Carioca, em 1951. Em 1954 passa a escrever para o jornal Última Hora, mantendo sua coluna até 1968, ano de sua morte. Escreveu também para os jornais Tribuna da Imprensa, Diário da Noite e O Jornal, e para as revistas Manchete, Fatos \& Fotos, O Cruzeiro, Senhor e Revista de Música Popular. Participou da criação do jornal O Comício, dirigido por Rubem Braga e Joel Silveira, e do jornal Pif Paf, de Millôr Fernandes. Produzia textos humorísticos, comentários esportivos e programas sobre música popular para as rádios Mayrink Veiga e Guanabara.

Na televisão, meio de comunicação que começava a se impor no início dos anos 60, redigiu programas humorísticos e jornalísticos. Participou da programação da TV Rio, TV Tupi, TV Excelsior e TV Globo. Na TV Tupi lançou a célebre eleição das "Dez mais certinhas do Lalau", fazendo a paródia aos concursos das "Dez mais elegantes", promovidos pelos colunistas sociais da época, e ao mesmo tempo valorizando o teatro rebolado e a cultura popular. Compôs durante vários anos o grupo de jornalistas do Jornal de Vanguarda (1962-1968). Esse Jornal trouxe a linguagem informal e a presença de vários locutores para o telejornalismo, além de ter introduzido o comentário de jornalistas especializados (Newton Carlos e Villas Boas Corrêa) e o humor, por meio das figuras de Stanislaw e Borjalo. Para o cinema, escreveu os diálogos dos filmes É do Chuá (1958), E o Bicho não Deu (1959), e os argumentos dos episódios do filme As cariocas (1967). Para o teatro, escreveu várias revistas musicais como Brasil pede passagem (1965), sobre Castro Alves, e Show do crioulo doido, em que contava a história da música popular brasileira.

É patente, portanto, a relação de Stanislaw com os meios de comunicação de massa, que ele ajudou a constituir. Stanislaw fazia parte de um conjunto de intelectuais que escreviam simultaneamente em vários meios de comunicação e que, muitas vezes sem o perceberem, estavam construindo uma nova linguagem — sintética, metafórica, leve e bem humorada —, própria para esses veículos: o jornal, o rádio, o teatro musical, o cinema e a televisão. As experiências artísticas adotadas em um veículo eram copiadas em outro, formando um sistema de comunicação mais ou menos homogêneo. Eviden- 
temente, as características dos veículos eram levadas em consideração no momento da elaboração dos textos e é possível perceber a busca da linguagem adequada, do tom apropriado, de um aproveitamento eficiente dos recursos expressivos de cada meio de comunicação e forma artística.

Embora este artigo realize somente a análise literária e a reconstrução da ambientação histórica de parte da obra do autor, é relevante deixar indicado que Stanislaw era um intelectual completo, muito produtivo, intenso e minucioso. Para a edição de seus livros, Stanislaw selecionou as crônicas publicadas no jornal Última Hora e nas revistas Manchete e O Cruzeiro. Percebe-se uma preocupação do autor em produzir livros orgânicos, estabelecendo relações entre as crônicas, as ilustrações e o projeto gráfico. As imagens, charges de Jaguar, foram feitas especialmente para cada crônica. Jaguar, um dos chargistas mais conceituados do humorismo político da época, colaborava nos mesmos jornais e revistas. Podemos dizer que Stanislaw e Jaguar eram amigos e cúmplices no projeto artístico e ideológico. ${ }^{3} \mathrm{O}$ chargista compunha, de certa forma, o cenário de representações coletivas presentes nos textos de Stanislaw, fazendo a ligação entre um corpus de imagens humorísticas tradicionais e os conteúdos textuais da crônica de Stanislaw. O leitor poderia fazer duas leituras, em paralelo, ou complementar o raciocínio sugerido nas crônicas por meio da apreciação das imagens. No entanto, é bom frisar que o espaço reservado nas páginas dos livros às ilustrações de Jaguar era significativo, sugerindo uma autonomia autoral em relação às crônicas. Para este artigo selecionamos algumas charges de Jaguar, Fortuna e Ziraldo com o objetivo de recompor, minimamente, a ambientação gráfica e discursiva em que a crônica de Stanislaw era recebida pelos leitores.

Para nos aproximarmos dos leitores de Stanislaw, é preciso escrever algumas palavras sobre o jornal Última Hora e sobre o lugar social de onde falavam estes intelectuais-artistas. Stanislaw dirige-se a um público variado, leitores da pequena imprensa, da imprensa alternativa e da grande imprensa; esta última estava se constituindo e ainda não havia definido totalmente os códigos de produção e recepção. Como em épocas anteriores, em que se permitia o diálogo rápido entre os donos de jornais, os jornalistas e a comunidade de leitores, Stanislaw vai colhendo material da própria imprensa e produzindo um novo texto selecionando, recortando, omitindo e reordenando os fatos. A crônica indicava a projeção de dois destinatários: o leitor médio, popular, que seria seduzido por meio do emprego da linguagem coloquial, do uso de grosserias, obscenidades e imitação, muitas vezes, de piadas conhecidas; e o leitor idealizado, possivelmente intelectualizado ou engajado no de- 
bate político, e por isso munido de referências históricas e culturais para entender as mensagens. A correspondência que faz publicar em sua coluna no jornal Última Hora funciona como um índice de modos de interpretação, pois sugere a existência de uma comunidade de leitores que compartilham as mesmas idéias. De certa forma, a publicação e o comentário de cartas fornecem protocolos de leitura para as próximas crônicas: ensinam a decifrar os jogos de pensamento e linguagem.

O fato de a coluna de Stanislaw Ponte Preta ser publicada em um jornal de tiragem nacional, Última Hora, famoso por ter sido o órgão de comunicação do segundo governo Vargas (1951-1954), associado ao local a partir do qual se olha o Brasil, isto é, o Rio de Janeiro, capital federal e centro do debate político, conferiam à crônica uma visibilidade especial: garantia uma grande repercussão nacional. A coluna era o lugar institucionalizado da subversão humorística. Nesse jornal lia-se, simultaneamente, o texto eminente, oficial — isto é, o texto parodiado —, e o seu duplo, a paródia satírica.

Há algumas particularidades a serem ressaltadas na história do Última Ho$r a$. Esse jornal criou e projetou muitos jornalistas. Samuel Wainer, proprietário do veículo, conta que teve dificuldades em recrutar profissionais à época da sua fundação, em 1951, logo após a volta de Getúlio Vargas ao poder. Muitos jornalistas, que haviam sofrido perseguições no tempo do Estado Novo, se recusavam a integrar a redação, com receio de serem identificados ideologicamente com o ex-ditador. A solução encontrada por Samuel Wainer foi oferecer a esses jornalistas colunas assinadas, em que teriam liberdade de opinar. O colunismo tinha desaparecido dos jornais durante o período de censura getulista e as primeiras colunas despertaram o interesse do leitor. Com o tempo, o jornal se especializou, incorporando um amplo leque de interesses em suas colunas, todas assinadas. O jornal era um verdadeiro caleidoscópio, nas palavras de Paulo Silveira, seu diretor, estabelecendo "corredores de comunicação" com os mais variados setores da opinião pública. Havia muitas crônicas de costumes, assinadas por Nélson Rodrigues e Antônio Maria, entre outros. Colunas especializadas em política nacional e política internacional dividiam o espaço com textos de intelectuais e jornalistas que escreviam sobre cinema, literatura, teatro, música popular e televisão. Sociólogos e economistas foram aproveitados como colunistas, inaugurando uma nova modalidade de jornalismo, analítica e conjuntural. O colunismo social e os esportes, assim como a cobertura dos casos policiais e dos problemas da cidade, não foram esquecidos.

Os jornais estavam passando por um processo de modernização gráfica e enfrentando as conseqüências das mudanças significativas no público lei- 
tor, que se tornava cada vez mais diversificado. O Última Hora respondeu convenientemente às novas circunstâncias sociais. As colunas temáticas, por exemplo, foram fundamentais para o sucesso do jornal, pois permitiram uma economia de recursos e a fixação do leitor, como explica Paulo Silveira:

Tínhamos, por exemplo, Jacinto de Thormes, que era o colunista da classe A; publicávamos Sérgio Porto, que representava o mais puro humor carioca; Antônio Maria, o homem da noite, do meio artístico, o compositor consagrado; o Marijó, que era o colunista da reivindicação popular; havia o Carlos Renato, que representava a vida social dos subúrbios e, claro, muitos outros colunistas que se dirigiam praticamente a todos os interesses.

O somatório dessas colunas transformava a Última Hora numa espécie de caleidoscópio, onde cada leitor, fosse da classe A, da classe B ou C, se encontrava com o seu colunista. ${ }^{4}$

Nossa pesquisa, como o leitor pode observar, focaliza as representações sociais e as memórias concorrentes que se produziram no período de gestação e consolidação da ditadura militar. Considerando que se trata de um fenômeno histórico total a ser estudado, não podemos deixar de lado a experiência, os sentimentos e as percepções dos agentes sociais. Esses agentes sociais formam grupos distintos, com projetos e entendimentos diferentes acerca da realidade. $\mathrm{O}$ historiador, no seu trabalho de pesquisa e interpretação, depara-se com o imperativo de uma "estrutura mental" que, ao lado de outras determinações históricas, estão informando e orientando ações sociais. ${ }^{5}$ Além do mais, "as representações sociais não são estruturas neutras", como nos lembra Chartier. Elas são fruto de interesses específicos de grupos sociais, que disputam a hegemonia política e discursiva em relação à interpretação correta de uma dada situação social. Dessas representações se originam estratégias e práticas sociais. ${ }^{6}$

Da mesma forma que o conceito de representação, o conceito de memória mostrou-se operacional neste estudo, porque a matéria histórica analisada indicava uma disputa entre memórias históricas inseridas como argumentação no debate político. Os grupos sociais envolvidos no processo histórico forjaram tradições, buscaram pais fundadores, discursos e estilos que legitimassem a sua posição; produziram narrativas históricas, com o objetivo de criar identidades e diferenciações. Simultaneamente à criação da memória histórica oficial - porque advinda do trabalho de interpretação do grupo hegemônico - , surgiram outras memórias, como a dos escritores humoristas de oposição. Segundo Michael Pollak, ao lado da "memória coletiva" é 
possível encontrar, através da pesquisa histórica, indícios de "memórias subterrâneas que prosseguem seu trabalho de subversão ... de maneira quase imperceptível". ' Em momentos de crise essas memórias entram em disputa. No caso dos textos humorísticos de Sérgio Porto, é possível identificar a construção e o aproveitamento de "memórias subterrâneas", que estão sendo acionadas como resposta à memória histórica produzida pela ditadura militar.

O uso da crônica humorística, como instrumento de compreensão da realidade política, demonstra a sua filiação à tradição intelectual e literária brasileira. No seu texto encontramos a dicção de Machado de Assis, França Jr., Martins Pena, Arthur Azevedo, Hilário Tácito (José Maria de Toledo Malta), Juó Bananére (Alexandre Ribeiro Marcondes Machado), Mendes Fradique (José Madeira de Freitas), João do Rio (Paulo Barreto), Antônio de Alcântara Machado, Belmonte (Benedito Carneiro Bastos Barreto), Lima Barreto e Barão de Itararé (Aparício Torelly), entre outros. Na história da literatura e da cultura brasileira, Sérgio Porto tem um papel singular. Conservou, recuperou e reinventou a crônica humorística de cunho político e de crítica dos costumes.

Os livros Garoto linha dura, Febeapá 1, Febeapá 2 e Na terra do crioulo doido - A máquina de fazer doido - Febeapá 3, publicados entre 1964 e 1968, constituem-se em um projeto literário e ideológico do autor, partilhado por outros escritores, pois estas eram as características da produção artística naquele momento histórico. O engajamento, a linguagem cifrada, o teor de defesa do regime democrático moldavam a produção artística. Na medida em que partimos do princípio de que se trata de um projeto de interpretação da realidade, as crônicas serão analisadas em conjunto, porque apresentam o processo de reflexão do autor, o amadurecimento dos temas, a busca de uma forma totalizadora de compreensão dos fatos políticos.

O assunto dos livros é a militarização do Estado e da sociedade civil. Para tanto o autor faz uma espécie de inventário e descrição dos discursos e ações do regime autoritário implantado em 1964. Primeiramente buscaremos determinar o tipo de foco narrativo elaborado pelo autor e, em seguida, analisaremos os processos de estilização e de paródias de diversas representações relativas ao golpe de 1964 .

\section{O PONTO DE VISTA DO NARRADOR}

Após o golpe de abril de 1964, a Junta Militar prometia "restaurar as instituições ameaçadas pelo comunismo internacional e pela corrupção dos po- 
líticos profissionais" e, em seguida, devolver o poder aos civis. Em 9 de abril, foi editado o Ato institucional $\mathrm{n}^{\circ} 1$, em que no preâmbulo os militares se identificavam como "revolucionários" e "representantes da vontade nacional":

É indispensável fixar o conceito do movimento civil e militar que acaba de abrir ao Brasil uma nova perspectiva sobre o futuro. O que houve e continuará a haver neste momento, não só no espírito e no comportamento das classes armadas, como na opinião pública nacional, é uma autêntica revolução.

A junta militar procurou justificar racionalmente o dito "processo revolucionário". Esperava convencer a sociedade por meio da elaboração de uma argumentação lógica e fundamentada em noções de Ciência Política e Direito Constitucional.

A revolução se distingue de outros movimentos armados pelo fato de que nela se traduz, não o interesse e a vontade de um grupo, mas o interesse e a vontade da Nação.

A revolução vitoriosa se investe no Exercício do Poder Constituinte. Este se manifesta pela eleição popular ou pela revolução. Esta é a forma mais expressiva e mais radical de Poder Constituinte. Assim, a revolução vitoriosa, com o Poder Constituinte, se legitima a si mesma... ${ }^{8}$

Esse modo de conceber o movimento militar foi contestado por vários setores da sociedade civil. A disputa pela representação correta dos acontecimentos políticos transformou-se, tanto no discurso político quanto no discurso jornalístico, em uma questão lingüística e semântica. Tratava-se de legitimar a interpretação correta e destruir argumentações do poder instituído. Os discursos eram citados, criticados e interpretados com grande entusiasmo. Carlos Heitor Cony e Edmundo Moniz chegaram a publicar, ainda em 1964, em livro, as crônicas escritas no calor da hora do processo golpista. O teor dos textos era o de contraposição entre definições estipuladas pelas Ciências Sociais ou socialmente aceitas das palavras revolução, democracia, golpe, contra-revolução e os significados atribuídos pelos militares a essas mesmas palavras.

Edmundo Moniz assim se expressava em 29 de maio de 1964:

Só se pode definir como revolução um movimento militar por impostura ou ignorância. Isto, evidentemente, é sabido pelos teóricos da Escola Superior de Guerra, a não ser que não correspondam à realidade os seus decantados conhe- 
cimentos no campo da sociologia e da história. O termo revolução já foi empregado, muitas vezes, arbitrariamente, para definir os putsche nas nações da América Latina. Mas esta maneira de definir apenas demonstra o atraso de certas nações que não tinham o conhecimento exato do que realmente passava em seu solo. O Brasil, hoje em dia, está prestes a passar para a área dos países desenvolvidos e possui todas as possibilidades para fazê-lo. O nível intelectual do Brasil não mais admite que se confunda revolução com movimento militar. ${ }^{9}$

O texto humorístico seguiu o mesmo caminho, procurando revelar as contradições do regime a partir de seu próprio discurso. Millôr Fernandes, na revista Pif Paf, ainda em 1964 escrevia:

Quem avisa, amigo é: se o governo continuar deixando que certos jornalistas falem em eleições; se o governo continuar deixando que alguns políticos teimem em manter suas candidaturas; se o governo continuar deixando que algumas pessoas pensem por sua própria cabeça; e, sobretudo, se o governo continuar deixando que circule esta revista, com toda a irreverência e crítica, dentro em breve estaremos caindo numa democracia. ${ }^{10}$

Desde 1964 até 1966 Stanislaw Ponte Preta dialogou com essas representações do regime político e, com a publicação do Febeapá 1 - Primeiro Festival de Besteira que Assola o País, deu forma definitiva à sua concepção desse debate ideológico. ${ }^{11}$ No início do Febeapá, Stanislaw Ponte Preta explicou:

É difícil ao historiador precisar o dia em que o Festival de Besteira começou a assolar o País. Pouco depois da "redentora", cocorocas de diversas classes sociais e algumas autoridades que geralmente se dizem "otoridades", sentindo a oportunidade de aparecer, já que a "redentora", entre outras coisas, incentivou a política do dedurismo (corruptela do dedo-durismo, isto é, a arte de apontar com o dedo um colega, um vizinho, o próximo enfim, como corrupto ou subversivo - alguns apontavam dois dedos duros, para ambas as coisas), iniciaram essa feia prática, advindo daí cada besteira que eu vou te contar. (Febeapá 1, p.5)

Nesse curto parágrafo Stanislaw imita o discurso do livro didático de história, identificando um marco histórico de fundação dos eventos que irão ser relatados. As aspas empregadas na palavra "redentora" já indicam a ironia, a intenção de desmistificação e de sátira ao discurso dos grupos militares que justificavam o golpe com os argumentos da salvação nacional e da defesa dos ideais democráticos. O aproveitamento da idéia de "ABC da conjuntura polí- 
tica" e o uso de uma sigla, Febeapá, algo muito comum na estratégia de propaganda administrativa dos governos militares e na forma de designar os agrupamentos políticos, mostraram-se artifícios muito eficientes no processo de comunicação com o leitor médio de jornal. ${ }^{12}$

A palavra cocorocas, por sua vez, é uma alusão ao pensamento conservador, moralista, autoritário. ${ }^{13}$ "Cocorocas", para o autor, não são apenas as autoridades políticas civis ou militares, mas também, os indivíduos que na vida cotidiana defendem uma mentalidade autoritária nos costumes e na prática política. Por fim, descreve como "cocorocas" agentes sociais muito importantes da ditadura militar: os adesistas, pessoas das "diversas classes sociais", que se sentem representadas pelo regime. ${ }^{14}$

No campo dos recursos estilísticos que provocam o riso, temos nesse trecho a citação da linguagem coloquial e dos erros gramaticais das autoridades "que se dizem otoridades". Com esse mecanismo, o autor produz um rebaixamento na imagem dos políticos e dos militares. ${ }^{15}$

Stanislaw tematiza uma dimensão do tempo histórico, ou seja, a aceleração dos eventos numa determinada "conjuntura" concebida como de "caos":

O resumo abaixo foi feito na coluna "Fofocalizando", publicada no vespertino Última Hora ... São apenas tópicos colhidos pela agência informativa "Pretapress" - a maior do mundo, porque nela colaboram todos os leitores de Stanislaw - e aqui relembrados sem a menor preocupação de exaltar este ou aquele membro do Febeapá. Vão na base da bagunça para respeitar a atual conjuntura, e sua ordem é apenas cronológica. (Febeapá 1, p.6)

É importante notar que as condições históricas afloram no imaginário ficcional idealizado pelo autor como representações e não como matéria pura que estaria sendo por ele avaliada. O posicionamento do narrador é mimético, procurando todo o tempo inserir vozes sociais que representam novos hábitos culturais e novos estilos discursivos dos grupos ideológicos em conflito no cenário político mais visível, isto é, que eram freqüentemente citados pela imprensa e no debate parlamentar, e, portanto, formavam o imaginário social a respeito do golpe militar de 1964.

A representação dos acontecimentos históricos, produzida pelo olhar interessado e tendencioso dos agentes sociais e da imprensa, era a matéria básica das crônicas. Stanislaw não tem a intenção de explicar aquilo que foi considerado um "fato histórico", mas recuperar os modos de interpretação socialmente construídos. E, muito mais do que isso, dar a ver ao seu leitor o 
conflito, as tensões entre as fórmulas discursivas que procuravam explicar e legitimar essa ou aquela posição defendida pelos grupos sociais. Essa orientação do foco narrativo leva o autor a produzir um tipo de texto polifônico, dialógico, que mimetiza vozes sociais e produz o confronto entre mentalidades, ideologias, posicionamentos específicos e argumentações distintas.

Stanislaw vai modificando esse discurso, com independência, pois não adota o discurso politizado da esquerda; apenas apresenta as contradições com uma série de exemplos que desmentem o discurso oficial. A verdade aparece como se fosse ficção, produzindo um contra-discurso. A citação irônica é o recurso principal. A realidade é apresentada como se fosse ficção, e, com esse artifício, mantém-se a tensão entre o discurso manifesto e aquele omitido pelos militares, que aflora na escolha estratégica de notícias. É o caso exemplar de "O Matadouro":

A transcrição abaixo é de uma transcrição, isto é, transcrevemos do jornal de Nova Friburgo (RJ) a transcrição que fez de um decreto municipal: 'Decreto ${ }^{\circ}$ ' 166 - O prefeito Municipal de Nova Friburgo, usando das atribuições que lhe confere o artigo 20, 33 , da Lei n⿳ำ 109, de 16 de fevereiro de 1948, e considerando que o Marechal Castelo Branco tem-se conduzido na Presidência da República como um estadista de escol; considerando que o Presidente Castelo Branco com o seu manifesto de então Chefe das Forças Armadas foi o primeiro grito de alerta contra a corrupção e a subversão que assoberbava a Pátria brasileira; considerando que o Presidente Castelo Branco, como chefe da Revolução, baniu a subversão comunista e a corrupção do Brasil; considerando que o Presidente Castelo Branco trouxe a paz, a tranqüilidade à família brasileira; considerando que o Presidente Castelo Branco vem implantando no País o clima de ordem, respeito e trabalho; considerando que o Presidente Castelo Branco, como herói da FEB, se fez credor da gratidão do povo brasileiro, decreta: - Artigo $1^{\circ}$ - Fica denominado Praça Presidente Castelo Branco o logradouro público conhecido por Largo do Matadouro - (ass.) Engenheiro Heródoto Bento de Melo - Prefeito. (Febeapá 2, p.30-1, grifos nossos) ${ }^{16}$

Nota-se que a palavra transcrição é mencionada quatro vezes no início do texto. A orientação irônica, da citação com distanciamento crítico, é reiterada com exagero pelo autor.

Esse texto é particularmente interessante para observarmos a orientação artística do autor, que é capaz de mostrar a realidade como ficção e a ficção como realidade, e, no jogo de enunciações, estabelecer relações não previstas 
entre comportamentos e representações. A arte é uma pintura de efeitos de realidade, depende da articulação adequada de meios expressivos. Nesse caso, o autor utiliza-se da linguagem alusiva, que relaciona o Presidente Castelo Branco ao sistema repressivo e, por isso, a palavra matadouro assume a posição de sinônimo dos atos do governo. O olhar de Stanislaw é perspicaz, espertíssimo, e, provavelmente, acrescenta mais uma alusão ao procedimento artístico quando cita o nome do prefeito, Heródoto, nome de autor conhecido como o criador do discurso historiográfico.

Em outros momentos diz:

Algumas frases lapidares, que serviram para incrementar a besteira, como por exemplo - "O que é bom para os EUA é bom para o Brasil" (Juracy Magalhães) ou então "Aceito minha noiva como legítima esposa para cumprir o meu dever com a pátria" (Padre Vidigal) são marcos da História Contemporânea do Brasil, e suscitaram outras tantas frases, assim como outras tantas atitudes, cujo relato o sociólogo Stanislaw apenas assinala, por ser um observador e não um novidadeiro. (Febeapá 2, p.17, grifos nossos)

Prefiro sempre transcrever, como fazem os outros historiadores. (Febeapá 2, p.78)

Na matéria misturada da sátira política, Stanislaw recolhe uma série de depoimentos de militares, representantes dos poderes Executivo e Legislativo, que visavam explicar e justificar a ação política do governo. As declarações governamentais são contraditórias, o esquema argumentativo acaba por inverter as razões e os fatos. O discurso oficial manipulava a linguagem e os sentidos, distorcendo os fatos e o processo lógico. Stanislaw assinala esse recurso retórico característico do discurso institucional:

Como eu dizia linhas acima, uma das mais constantes manifestações do Festival de Besteira, na sua fase presente, é a mania de querer explicar o que não tem explicação. Muito melhor é não dar explicação nenhuma. (Febeapá 2, p.26)

Stanislaw usa a "verdade" como arma para conscientizar o público, pois está inserido em um projeto utópico de instituir a democracia no país. É interessante notar a visão analítica que ele adota, ao escolher as "verdades" mais adequadas, com o objetivo de mobilizar o leitor, levá-lo à ação. ${ }^{17}$

Cita discursos que tratam de coisas concretas, práticas, efetivas, próximas do leitor. Não há abstrações, ou discussões conceituais. $\mathrm{O}$ tom do discurso é intencionalmente agressivo, por isso satírico, aos poderosos, aos milita- 
res. Mas não deixa de representar as fraquezas, ou vícios, dos dominados: a corrupção, a delação, o oportunismo, a alienação política, enfim, o autoritarismo socialmente implantado na sociedade civil. No Febeapá encontramos enredos aparentemente inocentes, que, talvez, não fossem compreendidos pela censura na sua significação profunda. São exemplos da disseminação do comportamento autoritário nas relações sociais mais cotidianas. De maneira oblíqua e microscópica, procura transmitir uma visão analítica da estrutura das relações de poder. Conforme diz Paulo Sérgio Pinheiro:

para se compreender os percursos através dos quais o autoritarismo socialmente implantado é engendrado ... e se reproduz, é essencial reconstituir a rede de microdespotismos nos mais variados contextos sociais: a violência familiar, discriminação racial, violência contra a mulher e a criança, justiceiros, linchamentos. Padrões autoritários que podem estar nas "pequenas autoridades" que se aperfeiçoam e se desenvolvem nos períodos de ditadura. ${ }^{18}$

\section{A REPRESENTAÇÃO SATÍRICA DOS MILITARES:}

\section{A CARICATURA DAS FORÇAS ARMADAS}

Quem são esses militares que se intitulam defensores da democracia? Vejamos a imagem humorística do coronel criada por Stanislaw:

O coronel brigou com o major porque um cachorro de propriedade do primeiro conjugava o verbo defecar bem no meio da portaria do edifício de onde o segundo era síndico. Por causa do que o cachorro fez, foi aberto um IPM de cachorro. King - este era o nome do cachorro corrupto - cumpriu todas as exigências de um IPM. Seu depoimento na Auditoria foi muito legal. Ele declarou que au-au-au-au. (Febeapá 1, p.25)

\section{Como contraponto, podemos ler:}

As Forças Armadas constituem uma de nossas classes produtoras. Produzem aquilo que mais vale, pois é a base sem a qual nada se poderia fazer de útil, ordenado e permanente: a segurança nacional. (Presidente Costa e Silva). ${ }^{19}$

Logo após o movimento golpista, os generais passaram a ser notícia no cinema, na televisão, nas estações de rádio, nos jornais, vestidos com fardas 
que simbolizavam a sua autoridade e valor. Apareciam em cerimônias de condecoração, desfiles de infantaria e cavalaria.

Os humoristas aproveitarem essa exposição nos meios de comunicação para criarem uma galeria de tipos fardados, caracterizados por manias de disciplina; excesso de organização; crença no progresso; valorização da ordem, autoridade e hierarquia. Como diz Kucinski, "os generais foram caricaturados com queixos proeminentes, bocas abertas a berrar, quepes e fardas recobertas de medalhas que exibiam emblematicamente o jogo do poder e do autoritarismo. ${ }^{20}$ Essas características estavam ligadas à forma como o público leitor e os meios de comunicação representavam os militares. A produção humorística de Millôr, Fortuna, Ziraldo, Jaguar e Stanislaw Ponte Preta segue essa convenção literária. ${ }^{21}$

Podemos lembrar o conto "Sempre Alerta", em que Millôr conta a história de um escoteiro, muito solidário, que resolve ajudar um velhinho a tomar o ônibus. Mas o escoteiro está com um cão feroz. O velhinho só consegue alcançar o ônibus porque o cão o está perseguindo. A moral da história é: "No cerne da violência, nem sempre há violência: Au! Au!". Millôr recupera de maneira paródica a fábula do "lobo vestido de cordeiro". O escoteiro, com a farda característica, representa o militar. O cão representa o aparato repressivo e o velhinho, o povo, cidadãos submetidos à violência. A moral da história é irônica, citando o discurso da não-violência que era veiculado pela ditadura militar. $\mathrm{O}$ distanciamento irônico induz o leitor a uma interpretação pelo avesso, isto é, não há justificativa para a prática de violência. ${ }^{22}$

Stanislaw está dialogando com algumas representações dos militares presentes na sociedade: a imagem construída pelos próprios militares, a representação coletiva veiculada pelos meios de comunicação e órgãos do cerimonial do governo e a imagem construída pelos humoristas. Parodiando o própria convenção humorística da época, interpreta de maneira diferente a representação do cão como instrumento repressivo. Associa o cão aos excrementos corporais, produzindo o destronamento do poder instituído.

A imagem proposta pela corporação militar é desfocada pela situação cômica de um coronel e um major acionarem um IPM para resolverem o conflito de vizinhança causado pelo cachorro. O despropósito da situação ficcional é análogo ao despropósito de situações reais envolvendo as forças militares e os suspeitos de subversão. $\mathrm{O}$ aparato repressivo estava fundamentado na ideologia da Segurança Nacional, elaborada pela ESG - Escola Superior de Guerra, a qual considerava que o país estava em guerra interna. Para efetivar a repressão foram criados o SNI - Serviço Nacional de Informações e os 
IPMs - Inquéritos Policiais Militares, em 1964. Esses instrumentos de repressão são constantemente citados por Stanislaw Ponte Preta. Os aparelhos de repressão são interpretados do ponto de vista das pessoas comuns, em situações de seu cotidiano.

Na crônica "O Sabiá do Almirante" discutem-se as noções de força-fraqueza, autoridade-autoritarismo, de uma maneira invertida. O militar deveria ter autoridade e o ladrão usaria a violência; na crônica, no entanto, o ladrão invade o quintal do Almirante para roubar um sabiá, passarinho de estimação do dono da casa. O Almirante se orgulhava do canto do sabiá e isto o tornava popular entre os vizinhos. Para evitar o roubo, o Almirante usa um instrumento de força, um revólver calibre 45. O diálogo entre os dois serve para humilhar o ladrão. A força das palavras e a ameaça com o revólver são desproporcionais ao evento:

- Pois tu vais botar o sabiá na gaiola outra vez, vagabundo. Vai botar o sabiá lá, vai me pedir desculpas por tentar roubá-lo e depois vai me jurar por Deus que nunca mais passa pela porta da minha casa. Aliás, vai jurar que nunca mais passa por esta rua. Tá ouvindo? (Febeapá 1, p.67)

O ladrão simula abandonar o quintal, pulando o muro. O Almirante, "satisfeito consigo mesmo", vai ao cinema. Na volta percebe que o sabiá havia sumido. Portanto, o ladrão não se atemorizou tanto assim.

Na crônica "Zézinho e o Coronel”, do livro Febeapá 2 (p.92-5), os pares forte-fraco, autoridade-autoritarismo se repetem. O coronel Iolando é um personagem autoritário, não permite que as crianças joguem bola na calçada. Parece uma "onça com sinusite". A ferocidade do coronel é tamanha que chegou a colocar dois guardas para vigiar a rua. Era um "frankenstein de farda". A filha dele, Irene, passa a namorar Zezinho. Um dia, quando o coronel estava se preparando para "comandar um batalhão no combate à passeata de estudantes”, descobre o namoro. Sua reação é violentíssima:

Tirou o trabuco do coldre e desceu a escada de quatro em quatro degraus, botando fumacinha pelas ventas arreganhadas. Parecia um búfalo no inverno.

Ameaça Zezinho com o revólver:

- Pois eu lhe enfio o cano no olho e descarrego a arma dentro da sua cabeça, seu cafajeste. 
Depois da ameaça, o Coronel “foi cercar os estudantes na passeata”. O narrador insiste em se referir aos fatos relacionados ao movimento de resistência estudantil. O coronel era chamado pelo apelido de Ioiô, pela sua mulher. Esse é um recurso de linguagem para produzir o destronamento do personagem. No desfecho da história ficamos sabendo que a mulher do coronel está com pena do marido, porque Irene e Zezinho haviam saído para casar na igreja. Para afrontar o coronel, haviam deixado um abraço a ele.

A crônica encena a luta entre o bem e o mal. O mal está concentrado na figura do Coronel, representado por imagens de animais (onça com sinusite, búfalo no inverno) e pela fantasia de Frankenstein. O lugar do bem está ocupado por Zezinho, tipo de estudante alienado, paquerador, que, portanto, destoa da representação do estudante ligado ao movimento estudantil. Dessa forma a imagem do estudante também se transforma, na crônica, pois a persona satírica enfraquece a representação social, que associava o movimento estudantil aos métodos do terrorismo comunista. A crônica articula e deturpa concepções construídas socialmente em relação aos militares e estudantes. Tanto o estudante Zezinho quanto o coronel Iolando não correspondem ao imaginário institucional dos grupos sociais que representam. A crônica expõe o personagem do militar ao ridículo, pois ele não conseguiu, apesar da força manifestada, evitar o namoro da própria filha. E Zezinho, com as armas da malandragem, foi capaz de driblar a perseguição.

Tanto na crônica "O Sabiá do Almirante", quanto em "Zezinho e o Coronel”, Stanislaw quer mostrar que o autoritarismo não consegue atingir os seus objetivos e que, no cotidiano, há um processo de resistência ao sistema político.

No que diz respeito aos atributos do Coronel, devemos lembrar que os humoristas associavam os militares a características de animais. Jaguar, por exemplo, cristalizou a imagem do cavalo para desenhar os militares. A palavra "cavalo", em linguagem popular, é uma metáfora pejorativa, que significa indivíduo violento, grosseiro, rude, estúpido. Pode ser usada como vitupério, sinônimo de "animal" e "cavalgadura". "Cão", por metáfora significa pessoa muito má e, na cultura popular, representa o diabo. Podemos dizer também que, nas duas crônicas, trata-se de desenvolver o tema do ditado popular: "cão que ladra não morde". ${ }^{23}$

Uma outra forma de se referir aos militares é usar o título de marechal. De maneira programática os analistas políticos e cronistas referiam-se aos presidentes de Marechal Presidente. Exemplos em Stanislaw:

Enquanto o Marechal Presidente declarava que em hipótese alguma permitiria fosse alterada a ordem democrática por estudantes totalitários, insuflados 
por comunistas notórios, quem passasse pela Cinelândia do dia $1^{\circ}$ de Abril depararia com o prédio da Assembléia Legislativa totalmente cercado por tropas da Polícia Militar.

Na certa a separação de poderes, prevista na Constituição, passará a ser feita com cordão de isolamento e muita cacetada. (Febeapá 3, p.24) ${ }^{24}$

Pelo menos, não se discutiu sobre aquela constitucionalidade que o falecido marechal nos legou... (Febeapá 3, p.123) ${ }^{25}$

Nas duas citações, os presidentes estão associados a situações de autoritarismo. A palavra Marechal, a princípio, parece uma denominação protocolar, convencional. No entanto, devemos associá-la à figura do cavalo e entender o objetivo ofensivo embutido nessa denominação. O exército se constituiu historicamente em torno da cavalaria e isso é lembrado intencionalmente no discurso satírico, como uma forma de degradação da função militar. A palavra deriva do francês e no século XI significava "artesão encarregado das ferraduras dos cavalos", "criado doméstico que cuida de cavalos". ${ }^{26}$ Por analogia o marechal seria um homem rude, criador de cavalos, ou propriamente estaria assumindo as características do animal. Estas acepções estão contidas no discurso satírico e produzem o efeito de rebaixamento da imagem do militar. É a imagem literária correspondente à caricatura desenhada pelos chargistas. Na história do humor brasileiro, a convenção de ridicularização do marechal começa com as caricaturas feitas em torno da figura do Marechal Hermes da Fonseca, que era representado como um presidente autoritário, que não respeitava os direitos individuais e seria um homem azarado. Essa imagem de ditador em pele de presidente constituído reveste-se de humor ao ser justaposta à imagem de irreverência de sua esposa Nair de Teffé. ${ }^{27}$

\section{O CARÁTER VIOLENTO DO REGIME}

Conforme podemos observar, o autor produz textos literários que são o avesso do discurso militar. As qualidades socialmente atribuídas à polícia militar e civil - inteligência, ética, respeito às leis e regras da categoria profissional, confiança e proteção - são totalmente deturpadas. ${ }^{28}$ Em vez de proporcionar segurança e levar ao cumprimento da lei, no discurso satírico os policiais se valem da farda para atemorizar as pessoas. A sátira política encena o choque entre virtudes propostas como ideais e vícios identificados co- 
mo prática desse grupo social. A violência no exercício da profissão está presente nesta notícia:

Segundo Tia Zulmira "o policial é sempre suspeito" e — por isto mesmo — a polícia de Mato Grosso não é nem mais nem menos brilhante do que as outras polícias. Tanto assim que um delegado de lá terminou seu relatório sobre o crime político com estas palavras: A vítima foi encontrada às margens do rio Sucuriú, retalhada em quatro pedaços, com os membros separados do tronco, dentro de um saco de aniagem, amarrado e atado a uma pedra. Ao que tudo indica, parece afastada a hipótese de suicídio. (Febeapá 1, p.15-6)

O suicídio não era uma hipótese, mas a causa oficial, dada pelos organismos de repressão, à morte de prisioneiros políticos. Um outro discurso, manifestado em grupos de oposição, denunciava os assassinatos cometidos durante as torturas. A palavra suicídio era usada como um eufemismo, para esconder a prática de violência. Tia Zulmira deturpa dois lugares-comuns nestas notas febeapianas: "o acusado é sempre inocente até que se prove o contrário" - princípio do processo criminal; e "o suspeito é sempre culpado até que ele prove o contrário” — prática do sistema policial e investigativo adotado pelos militares. O pensamento do algoz é desmascarado pela inversão do lugar-comum.

Na crônica "O Boateiro", de Garoto linha dura, temos o artifício de ficcionalizar os discursos. Stanislaw assinala que a história é fictícia. Notícias sobre prisão de presidente, comunistas incendiando igrejas, morte de cardeal são boatos. Um coronel resolveu "dar uma lição ao boateiro, levou-o a um pelotão de fuzilamento, somente para intimidá-lo". O coronel ameaça: "Fica espalhando mais boato idiota por aí, que eu lhe mando prender outra vez e não vou fuzilar com bala de festim, não". O boateiro, intimidado, traduz o que aconteceu a uns conhecidos: "O nosso Exército está completamente sem munição” (Garoto linha dura, p.112).

A idéia de ficção perpassa o conteúdo da crônica: o narrador afirma que a história é uma ficção, os boatos propagados pelo personagem são considerados ficção pelo personagem do coronel, o fuzilamento foi uma ficção (encenação), a afirmação final, no entanto, ao propor como verdade a aparência do fato, assinala uma outra verdade que seria o contrário do que está sendo dito.

A situação política apresenta-se como uma dualidade: aparência e essência, discurso expresso e ação praticada, enfim, o visível e o invisível. Em $\mathrm{Na}$ terra do crioulo doido - Febeapá 3, encontramos a seguinte nota, direcionan- 
do a leitura dos textos para a mesma operação de decifrar os códigos propostos pelo discurso militar.

\section{Duro ma non troppo}

O Ministro dos Transportes Mário Andreazza declarou em Belo Horizonte que "a crise política é 'artificial', pois o País está em franco desenvolvimento, e enquanto o Presidente Costa e Silva for Presidente, a Constituição será preservada, de sorte que qualquer endurecimento não ultrapassará os limites". (Febeapá 3, p.45)

Note-se a atenção do autor em colocar as aspas no texto citado e em certas palavras significativas para o entendimento da mensagem. $\mathrm{O}$ uso de aspas é uma forma de comentário sobre o que está sendo citado. A frase "Duro ma non troppo" refere-se a uma distinção que os jornalistas políticos fizeram entre os grupos militares autores do golpe: de um lado haveria a "linha dura", formada pelos tradicionalistas, de extrema direita, anticomunistas, ligados à tropa, aos valores da caserna e defensores do fechamento político; de outro lado existiriam os militares e civis, ditos intelectuais, formados pela Escola Superior de Guerra, com um projeto bem desenhado de reforma das instituições. Essa divisão era uma estratégia discursiva de dominação. As tendências se mantiveram interdependentes. Mesmo os militares mais intelectualizados, que tiveram contado com a ESG, mantiveram uma posição de valorização da tropa e dos princípios militares. As relações entre civis e militares foram dinâmicas. Houve alternância no poder e na prática política, ora mais aberta e legalista, ora mais fechada e violenta. ${ }^{29}$ Todo esse processo de argumentação e contra-argumentação, representação e auto-representação dos grupos sociais está mimetizado no texto paródico, que visa conduzir o leitor médio do jornal para a reflexão das contradições. A persona satírica nessa nota do Febeapá adota o ponto de vista da oposição, e, portanto, dirige-se também ao poder militar, tentando demovê-lo da prática de violência.

\section{O CULTO À MEMÓRIA DOS FEITOS MILITARES}

Outro elemento que merece destaque é a percepção do autor sobre a estratégia do Estado Autoritário Militar em construir uma memória do regime, que veiculasse uma imagem homogênea e positiva da atuação militar. Stanislaw faz uma releitura humorística do "fato histórico": 
O general Olímpio Mourão Filho doava ao Museu Mariano Procópio, de Juiz de Fora, a espada e a farda de campanha que usava como comandante das forças que fizeram a "redentora" de $1^{\circ}$ de abril. Isso é que é revolução; com pouco mais de dois anos já estava dando peças para museu. (Febeapá 1, p.20)

A imagem de Tiradentes não poderia sofrer modificações para não macular a respeitabilidade dos militares. Stanislaw registra a discussão pública:

Começa o novo martírio de Tiradentes! Um historiador mineiro levantou a questão, dizendo que Tiradentes barbudo e cabeludo era besteira, pois o mártir da Independência era alferes, e portanto usava cabelo curtinho, como todo militar. O blablablá comeu firme e obrigou o marechal-presidente a se manifestar, assinando um decreto que estabelecia a figura de Tiradentes a ser cultuada, isto é, seria a mesma da estátua do falecido colocada na frente do Palácio Tiradentes... (Febeapá 1, p.21-2)

A memória coletiva opera processos psicológicos e sociais de construção e desconstrução, lembranças e esquecimentos. A memória é seleção de eventos, adequados a projetos políticos e visão de mundo de grupos hegemônicos, mas revela disputas entre forças sociais. Como um espetáculo do poder instituído, a memória coletiva deve estar depositada em lugares e signos, com força persuasiva. Para que seja imediatamente reconhecida, depende de sinais concretos: uma estátua, um hino, uma pintura, um sítio geográfico, um calendário de comemorações. ${ }^{30}$

O narrador satírico observará os emblemas cultivados, os sinais mais espetaculares, e, sobre eles, cometerá os maiores sacrilégios. Toda alegorização do canto memorialístico original será parodiado, constituindo um novo canto também alegórico, pelo avesso, adequadamente desproporcional. Os $\mathrm{Fe}$ beapás são os lugares da memória do canto satírico: têm a força persuasiva semelhante àquela produzida pela memória oficial. ${ }^{31}$

As personagens míticas de Tiradentes, D. Pedro I, D. Pedro II, José de Alencar, Marechal Deodoro da Fonseca e suas respectivas imagens e memórias são descritas no estilo baixo e associadas a imagens obscenas e a comportamentos sórdidos. As crônicas afrontam esses objetos alegóricos, produzindo novas alegorias rebaixadas, ridículas, deturpadas em relação aos significados preestabelecidos.

A crônica "O Marechal e o Bêbado" incorpora uma figura central da memória militar, a do Marechal Deodoro, e a rebaixa, por meio da história de 
um bêbado que vivia à sombra da estátua, em uma praça do mesmo nome. $\mathrm{O}$ bêbado, único no local a respeitar a imagem do Marechal Deodoro, é ridicularizado pelos freqüentadores da praça. O bêbado é levado por alguns torcedores para assistir a um jogo de futebol. Na volta, muito mais alcoolizado, conversa com a estátua como se fosse o próprio Marechal Deodoro, manifestando um abuso de intimidade. Um policial chega e dá voz de prisão ao bêbado. Este, por sua vez, confunde-o com a figura do Marechal representada na estátua. A passagem é plena de irreverência aos signos do poder:

Sentindo-se protegido, o bêbado da Praça Marechal Deodoro, Maceió (AL), folgou mais pouquinha coisa, obrigando os ponderados a chamar a Polícia. Não demorou muito, veio um cavalariano, e o soldado, para assustar "aquele paud'água estrangeiro", atiçou o cavalo pra cima dele.

O bêbado nem se assustou, apenas olhou para o cavalo e, ao vê-lo, deu um sorriso de satisfação. Olhou para cima e gritou pro soldado.

- Ó Deodoro, você também veio, esse menino? Olhe... perdemos de dois a zero. (Febeapá 2, p.136)

Autorizado pela condição de pária social, bêbado, louco, desatinado, o bêbado explicita, pela confusão que produz, a apropriação que os militares fizeram da imagem histórica do Marechal.

No Febeapá 1, Stanislaw relata a notícia da suspensão da construção de um mictório público em frente à estátua de José de Alencar, em Fortaleza, a pedido do Instituto Histórico da cidade. Stanislaw usa o estilo cômico satírico, citando descontextualizadamente, ou talvez imitando parodicamente frases proferidas no documento oficial. Pratica, então, grosserias lingüísticas para referir-se ao culto à memória de José de Alencar. Com isso ele procura condenar essa prática de manipulação da história:

O Instituto tinha classificado de "incontinência histórica" a instalação de um sanitário ali, justamente quando se comemora o Centenário de Iracema. Agora o mictório está sendo construído atrás da estátua e o Instituto agradeceu à Prefeitura, ressaltando que "as pétreas narinas alencarianas não serão molestadas". Foi uma solução honrosa, sem dúvida, e agora, se alguém ficar aperreado, como se diz no Ceará, que vá atrás da estátua. (Febeapá 1, p.13)

Questionando a memória nacional, Stanislaw toca em questões específicas do ofício do historiador, como a questão do documento/monumento. ${ }^{32}$ 
Quando um evento ou personagem histórico se transforma em monumento, há uma diluição do caráter revolucionário ou contraditório das tensões sociais singulares. Stanislaw, por meio do cômico, repõe o elemento histórico, a particularidade, produz uma abertura para a interpretação dos mitos da história do Brasil.

Na nota do Febeapá 2 - De Pedro a Pedro, Stanislaw adota um estilo mais científico e discute, a sério, o fenômeno de criação desse tipo de história oficial, moralizada, estatal, que muitas vezes não corresponde a informações documentais. Stanislaw narra o debate em torno da publicação das cartas amorosas de D. Pedro II. Os historiadores oficiais, Pedro Calmon por exemplo, voltaram-se contra a revelação das cartas amorosas, alegando que isso poderia manchar a imagem tradicional de D. Pedro II. Stanislaw comenta: "É um fenômeno puramente nacional este de se criar uma personalidade exclusiva para a História, muito embora o personagem nada tenha a ver com essa personalidade" (Febeapá 2, p.47).

Chama atenção para a prática encontrada nos livros didáticos mais tradicionais, como o de Rocha Pombo, de construir uma narrativa histórica idealizada do Brasil, a qual acaba tendo mais uma função de difundir uma conduta moral que realizar um trabalho conseqüente de pesquisa documental.

O Sr. Pedro Calmon, na sua cocorocagem, ainda acrescentou: "em vida ele deu exemplo oficial dos bons costumes”. O que aliás, é verdade. Deu mesmo, mas isto não era mais do que sua obrigação. Em nada diminui o carinho do Imperador pela família, seu amor ao Brasil, o conhecimento de suas cartas amorosas. Mas como explicar isto aos homens que defendem a caduca História do Brasil, se Pedro Calmon é um dos eminentes historiadores do Brasil? (Febeapá 2, p.47)

\section{A SUBVERSÃO E A AMEAÇA COMUNISTA}

Afinal, o que é a ameaça comunista? Quem são os subversivos? O discurso satírico de Stanislaw volta-se para a reprovação da atmosfera de medo criada pela propaganda norte-americana do anticomunismo. Uma parte das crônicas do livro Garoto linha dura trata de duas perspectivas de entendimento do cenário político: o conceito militar de subversão, que estaria minando a sociedade civil, e a mentalidade de delação, praticada por grupos supostamente coniventes com a "ideologia da segurança nacional”. A persona satírica quer clarificar suas intenções, no prefácio do livro: 
Apenas para não deixar de homenagear ninguém, num país em que se vive a exaltação do medíocre, escolhi para título a história do garotinho que se deixou influenciar pelo mais recente método de democratização posto em prática no Brasil e lasquei no alto da página o nome: Garoto linha dura.

$\mathrm{Na}$ esperança de não ser considerado subversivo, subscrevo-me com cordiais saudações a todos. (Garoto linha dura, p.7-8) ${ }^{33}$

Vamos nos ater primeiramente a essa crônica, escolhida por Stanislaw para iniciar o livro. Em Garoto linha dura o narrador trata da introjeção do espírito de delação na vida cotidiana. Pedrinho, para fugir da repreensão do pai por ter quebrado a vidraça de sua casa, acusa o filho do vizinho pelo delito. A história é uma alegoria do sistema político. Segundo o narrador, "Pedrinho provou que tinha idéias revolucionárias".

Por meio das falas do garoto, o narrador revela o procedimento das prisões arbitrárias feitas pelo militares: “- Papai, esse menino do vizinho é um subversivo desgraçado. Não pergunte nada a ele, não. Quando ele vier atender a porta, o senhor vai logo tacando a mão nele" (Garoto linha dura, p.9-10).

$\mathrm{O}$ aparato repressivo do sistema militar acolhia acusações de subversão sem que houvesse preocupação em investigar a veracidade dos fatos e a confiabilidade dos informantes. O testemunho do delator, anônimo e enquadrado no conceito de opinião pública, era o bastante. Nos manuais de orientação dirigidos aos agentes dos setores de informação, lia-se: "Quando o fato é notório, este independe de provas, conforme preceito geral do direito, que aboliu o sistema de certeza legal, libertando o julgador de preconceitos textuais". ${ }^{34}$

Os militares fundam um "direito novo", baseado no julgamento de valor de pessoas da sociedade civil. Assim, professores, intelectuais, artistas foram presos por serem considerados "subversivos, comunistas e agitadores" por uma suposta "opinião pública", convenientemente vaga e indefinida. Outro critério para que a acusação de subversão fosse aceita sem problemas era o dos laços de família: filhos e parentes de pessoas consideradas comunistas "herdavam" o rótulo de subversão.

A ambigüidade da noção de subversão e a prática repressiva são reprovadas na sátira. A estratégia discursiva é a de propor situações em que o subversivo é inocente ou o delator é mal intencionado. No caso da crônica "O Revolucionário", o marido aproveita o ambiente de terror instaurado após o golpe para convencer a esposa de que corre o risco de ser considerado subversivo e ser preso. Cria a figura fictícia do Coronel Pereira, que o estaria procurando. Com essa artimanha, consegue ficar longe de casa por alguns dias. 
Ele usa esse subterfúgio para passar alguns dias com uma mulher deslumbrante. A crônica diverte, desfaz o clima de tensão e a imagem da ameaça comunista reiterada pelo governo. $\mathrm{O}$ texto contém o discurso de direita, favorável às prisões, e o discurso da esquerda, que busca denunciar as prisões arbitrárias. Cria-se uma terceira voz, irreverente e descompromissada, mas certamente o ridículo da situação se revela.

O ano de 1964 foi marcado por uma repressão drástica, baseada nas "operações de limpeza", também chamadas "operações pente fino" e "arrastão". Os policiais militares faziam manobras de detenção em massa, com bloqueio de ruas, busca de casa em casa e revista individual. Nos primeiros meses do governo militar, teriam sido presas 50 mil pessoas, especialmente líderes sindicais e estudantis, intelectuais, professores, estudantes e participantes de movimentos católicos. Os militares faziam detenções temporárias, aplicavam espancamentos e liberavam os prisioneiros antes que advogados pudessem apresentar pedidos de habeas corpus. As "operações pente fino" e "arrastão" tinham como objetivo implícito criar uma atmosfera de medo e insegurança na sociedade.

No Febeapá essa atmosfera de medo e insegurança é representada por histórias que narram denúncias infundadas e um adesismo cego.

Lembre-se que notei o alastramento do Festival de Besteira depois que uma inspetora de ensino no interior de São Paulo, portanto uma senhora de um nível mais elevado pouquinha coisa, ao saber que seu filho tirara zero numa prova de matemática, embora sabendo que o filho era um debilóide, não vacilou em apontar às autoridades o professor da criança como perigoso agente comunista. Foi um pega-pra-capar e o professor quase penetra pelo cano. Foi preciso que vários pedagogos da região - todos de passado ilibado — se movimentassem em defesa do caluniado, para que ele se livrasse de um IPM. (Febeapá 1, p.6)

O autor demonstra que esse imaginário é construído com intenções políticas e que uma análise atenta das ações de censura e repressão tornaria evidente uma prática aparentemente irracional, porém eficaz quanto ao objetivo de marcar a presença e criar a impressão de que o olho da ditadura está em todo lugar: a prática de censura aos espetáculos teatrais é constantemente citada para demonstrar a ignorância dos censores e a interiorização do autoritarismo no seio da sociedade: $:^{35}$ 
Foi então que estreou no Teatro Municipal de São Paulo a peça clássica Electra, tendo comparecido ao local alguns agentes do DOPS para prender Sófocles, autor da peça e acusado de subversão, mas já falecido em 406 a.C. Era junho e o pensador católico Tristão de Ataíde, o mesmo Alceu de Amoroso Lima, uma das personalidades mais festejadas da cultura brasileira, chegava à mesma conclusão da flor dos Ponte Preta em relação à burrice reinante, ao declarar, numa conferência: "A maior inflação nacional é de estupidez". (Febeapá 1, p.12)

\section{A CARICATURA DOS MINISTROS E FUNCIONÁRIOS PÚBLICOS}

A representação do funcionalismo público é desqualificada por meio de chistes (trocadilhos fonéticos) e da justaposição de imagens relativas à ignorância, corrupção e ineficiência, tratamento semelhante àquele dado aos representantes do Legislativo.

Abril, mês que marcava o primeiro aniversário da "redentora", marcou também uma bruta espinafração do Juiz Whitaker da Cunha no Departamento Nacional de Estradas de Rodagem, que enviara seis ofícios ao magistrado e, em todos os seis, chamava-o de "meretríssimo". Na sua bronca o juiz dizia que "meretíssimo" [ $s i c]$ vem de mérito e "meretríssimo" vem de uma coisa sem mérito nenhum. (Febeapá 1, p.9)

Na crônica "Por trás do Biombo", Febeapá 1, narra a história constrangedora de um homem morto por atropelamento que espera a chegada da polícia. A demora é grande e pessoas curiosas e prestativas se revezam em atenções ao morto. Segundo o narrador:

A nossa imperturbável e deficiente Polícia se incumbe de amainar o espírito do próximo; o seu sentimento de solidariedade. $\mathrm{O}$ falecido pode morrer à hora que for que ficará estirado na calçada, exposto à curiosidade pública, porque as autoridades policiais só vão aparecer depois que o caso já caminhou para o perigoso terreno da galhofa e o falecido já goza da intimidade dos que passam.

O humorista, com sua escrita desconcertante, faz o povo comentar: "Puxa... Ainda não fizeram o carreto desse boneco!". O narrador já sabe o que se lerá nos jornais do dia seguinte: "O corpo do extinto ficou durante horas exposto à curiosidade pública, porque a perícia demorou a chegar (Febeapá 1, p.45-6). 
A sátira alcança, então, os deputados. O narrador explica que o Deputado Fioravante Fraga propôs um projeto de lei que obrigava as delegacias de polícia a manterem um biombo, para esconder os que morrem nas vias públicas. O narrador comenta que o biombo não é solução, pois é a polícia que chega atrasada. A crônica termina com a paródia do texto jornalístico: "O corpo do extinto ficou durante horas exposto à curiosidade pública, porque a Polícia demorou a chegar com o biombo". O exagero e a deformação no plano ficcional revelam a forma como a situação é criticada do ponto de vista social.

"Depósito Bancário", do livro Febeapá 1, adota os temas e o estilo popular do baixo corporal, para realizar o rebaixamento, verdadeira dessacralização, da imagem altiva do sistema financeiro nacional. Stanislaw aproveita o trocadilho, depósito de dinheiro (depositar) — depósito de fezes (defecar), para ridicularizar o Banímpar - Banco do Estado do Paraná, dirigido pelo grupo político ligado ao governador Nei Braga. ${ }^{36} \mathrm{~A}$ história é a seguinte:

um cidadão entrou no banco com vontade de ir ao banheiro mas, ao invés de se encaminhar para o dito, usou o tapete da entrada principal, onde deixou um montículo constrangedor e provocou o maior pânico. Na hora em que produzia o montículo o movimento era intenso, houve correria de senhoras, protesto de senhores, o gerente ficou indeciso e quase dá o alarma de assalto, mas depois recuou porque o que o cara estava fazendo no tapete não era assalto não. Enfim foi uma confusão dos diabos.

O governador foi avisado por um funcionário, que "usou o verbo vulgar para definir o que o cara fizera 'pra o banco'”. O governador interpretou o verbo no sentido figurado e respondeu: "Mas isto é um problema da SUMOC". ${ }^{77}$ O espírito jocoso da população criou algumas lendas: "Há quem afirme que o guarda foi posto ali para fornecer papel aos próximos depositantes". Stanislaw finaliza a crônica aproveitando novamente a ambigüidade das palavras: "De qualquer forma, foi um escândalo danado. Tendo — inclusive - o banco fechado, logo após o acontecimento. Uns dizem que fechou para balanço. Outros dizem que fechou para descarga" (Febeapá 1, p.47-8).

O olhar de recriminação e de moralização dos costumes administrativos não é específico do momento histórico da ditadura militar. A imagem dos maus funcionários foi sendo construída desde o início da produção humorística de Stanislaw. 
A crônica "Inferno Nacional", do livro Tia Zulmira e eu (p.130-1), conta a história de um defunto. O homem havia sido vereador pelo PTB - Partido Trabalhista Brasileiro, diretor do Instituto de Previdência e amigo de Tenório. ${ }^{38}$ Ao morrer foi direto para o inferno. Lá, Satanás o informa que o inferno é dividido em departamentos administrados por países. $\mathrm{O}$ falecido procura primeiramente os Estados Unidos, mas desiste de entrar porque lá o regime é muito rigoroso: "quinhentas chibatadas e duas horas de forno de duzentos graus pela manhã; à tarde o falecido deveria ficar numa geladeira de cem graus abaixo de zero até às 3 horas e voltar ao forno de duzentos graus". Todos os outros departamentos visitados adotam o mesmo regime. De repente o defunto descobre uma fila em frente ao departamento brasileiro. A fila era grande e as pessoas estavam risonhas. Conversando com um defunto, descobre que o forno e a geladeira estavam quebrados e o encarregado das quinhentas chibatadas só comparecia à repartição para assinar o ponto.

A crônica recupera dados precisos das circunstâncias históricas: cita o PTB, o populismo através da referência aos Institutos de Previdência, a violência política por meio da menção ao deputado Tenório Cavalcanti. O "inferno nacional” é particularizado. O narrador assume a representação do Brasil como o país do jeitinho, do rompimento das regras, da desordem. A crônica produz um julgamento desse vício e afirma um outro comportamento que seria virtuoso: o Estado democrático. ${ }^{39}$

\section{A CARICATURA DOS VEREADORES, PREFEITOS, DEPUTADOS E GOVERNADORES}

Em “O Puxa-saquismo Desvairado” (Febeapá 1, p.31-2), o autor trata do clientelismo e das relações de dependência política entre governo central e municipal. O prefeito de certa cidadezinha teria se cansado de mudar a placa com o nome da praça central sempre que mudava o presidente da República e teria resolvido o problema inaugurando definitivamente a placa com o nome da praça: "Praça Presidente Atual".

A crônica "O Candidato Ideal” (Febeapá 3, p.125-7) cita expressões populares para caracterizar os vícios mais freqüentes nos políticos profissionais. O candidato ideal para "a conjuntura política atual" deveria ter "mão de gato, pé-de-boi, cabeça-de-bagre, estômago de avestruz, espírito de porco”. É convenção satírica estabelecer comparações depreciativas entre os seres objeto de crítica e animais. Traduzindo as expressões para o sentido figurado, os políticos seriam sorrateiros como um gato; corpulentos e conservadores como um 
boi; medíocres e ruins como um bagre; "engolem" qualquer coisa desde que seja para o seu benefício, como faz o avestruz, e criam situações embaraçosas como um espírito de porco.

\section{REPRESENTAÇÃO HUMORÍSTICA DOS TRABALHADORES}

A partir do livro Garoto linha dura, de 1964, os trabalhadores passam a ser tratados como um objeto do discurso político militar. Sobre eles, Stanislaw levanta dois pontos de vista: a) o dos partidos políticos de esquerda (PCB, PSB) e agremiações do movimento estudantil, como a UNE e os CPCs Centros Populares de Cultura; b) a dos partidos conservadores e grupos militares.

Para a esquerda, a classe trabalhadora, organizada e consciente, aliada à burguesia nacional, setor mais progressista da sociedade, estaria prestes a fazer uma "revolução". Para a direita, a classe trabalhadora estaria sendo manipulada pelos grupos radicais formados por comunistas..$^{40}$

Na crônica "A Revolta Vacum” do livro Garoto linha dura (p.21-2), Stanislaw conta a história verídica, porque publicada em jornal, ${ }^{41}$ de uma vaca que ao atacar um "distinto agricultor", alcançou o revólver que ele mantinha na cintura e a arma disparou. $\mathrm{O}$ narrador, zombando do fato inusitado, considera que a vaca havia dado um tiro no agricultor. O texto, então, vai se desenvolvendo a partir de analogias entre os trabalhadores e a vaca. A vaca, como caricatura da classe trabalhadora, estaria reagindo, como grupo oprimido, à exploração dos "tubarões do leite e da carne". Cita o slogan da esquerda: "com as vacas armadas o leite vai secar, com as vacas armadas eu quero ver quem aumenta o preço do filé”.

A última frase expõe o ponto de vista contrário, isto é, a concepção política dos militares: "Resta agora a declaração da turma da direita, dizendo que quem está fornecendo armas para as vacas são os comunistas".

A vaca, objeto manipulável tanto pelo movimento de esquerda, quanto pela direita, nada diz e não tem consciência dos fatos em que está envolvida. Por meio de uma comparação depreciativa, Stanislaw ridiculariza os dois pontos de vista. Produz um rebaixamento de uma teoria da revolução, tão importante para o movimento operário e estudantil do período. Além disso, revela a inadequação, segundo o ponto de vista do narrador satírico, das declarações do governo em relação à oposição.

Em nota do Febeapá 2, sob o título "Do Contra” (p.73-4), Stanislaw es- 
colhe uma notícia que expõe o ponto de vista do empresariado sobre as reivindicações trabalhistas. O jornalista citado é contra a participação dos empregados nos lucros das empresas porque o empresário é o único a arriscar o seu capital, e é contra o décimo terceiro salário porque "o ano do nosso calendário se resume em apenas doze meses”. Stanislaw manifesta desaprovação e ataca o jornalista: "O Festival de Besteira que Assola o País tem grande aceitação nos jornais do interior".

A representação do operário fixada nas crônicas é sentimental e visa valorizar a classe. As histórias narram situações tragicômicas e buscam ressaltar incongruências. $\mathrm{O}$ tom humorístico, com seu riso fraco, mais reflexivo, reforça o procedimento literário de falar de coisas sérias através da comédia. ${ }^{42}$

Como exemplo, selecionamos a crônica "O Operário e o Leão", do livro Garoto linha dura (p.89-90). O narrador faz analogia entre as características da imagem do leão e do cordeiro, no mundo animal, e as lutas ideológicas do período. A crônica narra a história de um moço que conseguiu matar um leão que havia fugido de um circo. Depois do evento, jornalistas querem saber qual a profissão do rapaz, entusiasmados pela façanha. As autoridades felicitam o rapaz, agradecem e o homenageiam pela coragem de ter matado o leão. Quando sabem que o rapaz é um operário, a versão da história muda. No dia seguinte, os jornais publicam a manchete: "Leão acuado e indefeso morto por feroz agente comunista". A característica do leão - ferocidade - é transferida para o operário, enquanto o leão assume as características do homem: está indefeso e acuado. $\mathrm{O}$ texto traz com insistência exagerada a informação de que se trata de uma história ocorrida em um reino distante, procurando dissimular a referência ao contexto político-ideológico. O leão representa, nesse reino distante, o que há de mais violento e ameaçador.

A crônica apresenta a polarização entre forças armadas/leão e operário/homem. As qualificações - ferocidade e fraqueza - mudam de referencial entre a primeira e a segunda parte do enredo. Na primeira parte da crônica predomina a versão dos grupos de esquerda: o par leão/forças armadas é forte e o par homem/operário é fraco. Na segunda parte da crônica vence a versão dos grupos conservadores: o par homem/operário é feroz e o par leão/forças armadas é fraco. A sátira, através do jogo entre estereótipos e alegorias, ataca o discurso de dominação das forças armadas, o qual se baseava na afirmação da infiltração da ideologia comunista no país. 


\section{CONSIDERAÇÕES FINAIS}

A persona satírica adota diversos pontos de vista procurando reconstituir os variados modos de conceber as forças armadas, os funcionários públicos, os políticos e trabalhadores. Por meio do riso o autor busca organizar, estabelecer um sentido à matéria veiculada pelos meios de comunicação e à experiência vivida por ele e pelos colegas de profissão - os jornalistas e escritores, pela natureza de seu trabalho, podem ter uma visão em perspectiva, olhando tanto para o alto, para a estrutura do poder, quanto para baixo, em direção aos seus leitores. Os códigos de leitura propostos pelas crônicas e pela estrutura da coluna também são muito variados, pois há os leitores que sabem decifrar as mensagens e há o leitor médio da imprensa de entretenimento, que não sabe.

Trata-se de um momento de crise política, de indefinição social, de esperanças frustradas, como tantos outros da história política brasileira, como a crise do período monárquico e o processo de proclamação da República. Naquele momento, à população foi proposto um ambicioso projeto de modernização que não se realizava no plano das instituições políticas. ${ }^{43} \mathrm{O}$ gênero da crônica, especialmente a humorística, tanto no início da República como no período aqui estudado, oferece uma interpretação mais ou menos coerente dos acontecimentos políticos ao homem das ruas, leitor desatento de jornal. Com o tom da loucura, do nonsense, e da piada velhíssima, muito conhecida, o leitor encontra um espaço de racionalidade e de liberdade. A literatura, mais uma vez, tem a função de fornecer uma identidade nacional, configura modos de compreensão do que é ser brasileiro.

Por meio dos recursos da inversão de sentido, da citação paródica, da antítese, Stanislaw constrói uma grande máscara da ditadura militar, ou, melhor dizendo, uma contra-máscara, na medida em que o texto paródico induz o leitor a conceber o discurso parodiado como algo que também foi construído intencionalmente. $\mathrm{O}$ cronista elaborou um contra-discurso que, com o passar do tempo, transformou-se em um "lugar de memória" da experiência do golpe militar da perspectiva da vida privada, no sentido da expressão criada por Pierre Nora. ${ }^{44}$

O trabalho de garimpagem de expressões lingüísticas, de restauração das formas de expressão particulares dos grupos sociais, dos sentimentos e valores sociais da época, é uma característica importante do estilo literário de Stanislaw. Por fim, é sempre bom lembrar que o trabalho do historiador é, em grande parte, um trabalho de reconstrução histórica, de recuperação de registros ocultados no tempo. As crônicas humorísticas, com temas do cotidiano e do cenário político, fazem o jogo entre a esfera pública e a privada, e podem ajudar no conhecimento de dimensões da vida privada que não estão evidentes em outras fontes documentais. 


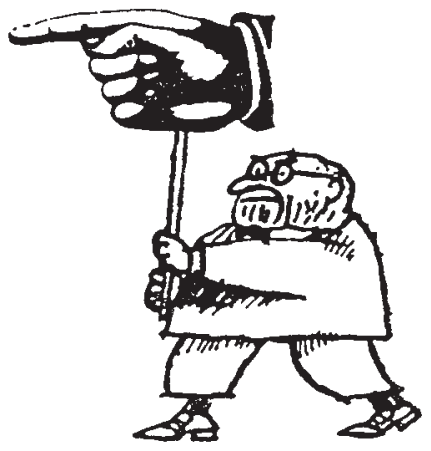

Ilustração de Jaguar para o início de Febeapá 1.

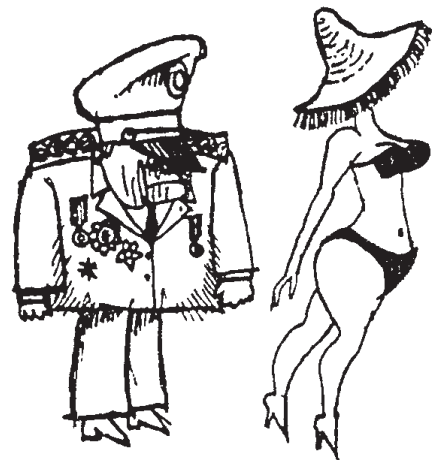

Ilustração de Jaguar para a frase "como se perna de mulher alguma vez tivesse ofendido as armas de alguém” (Febeapá 1).

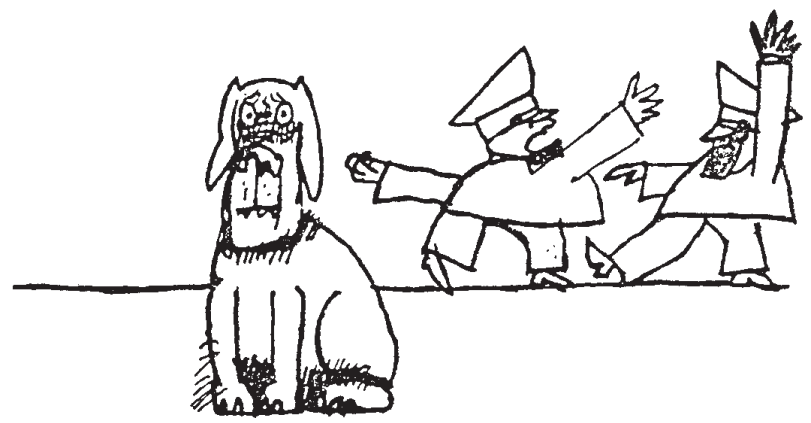

Ilustração de Jaguar para a anedota do IPM do cachorro King (Febeapá 1). 


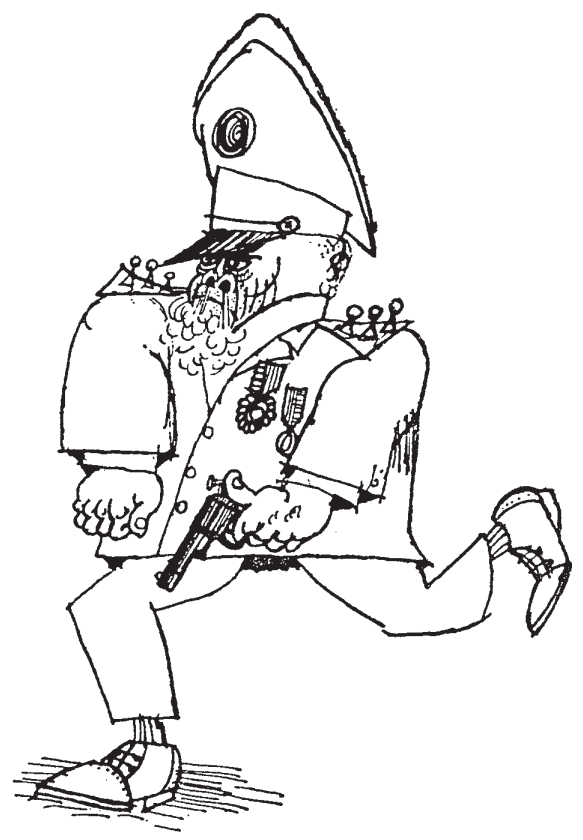

Ilustração de Jaguar para a crônica Zezinho e o Coronel (Febeapá 2).

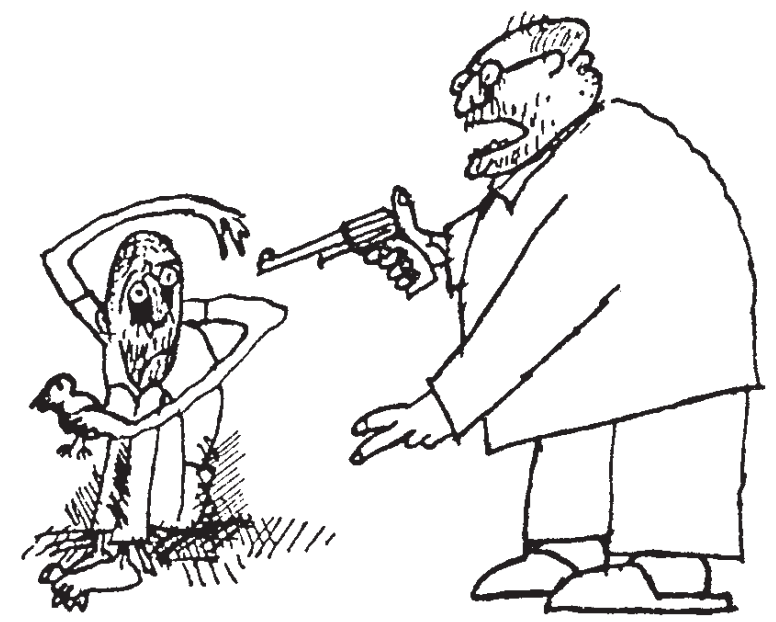

Ilustração de Jaguar para a crônica O Sabiá do Almirante (Febeapá 1). 


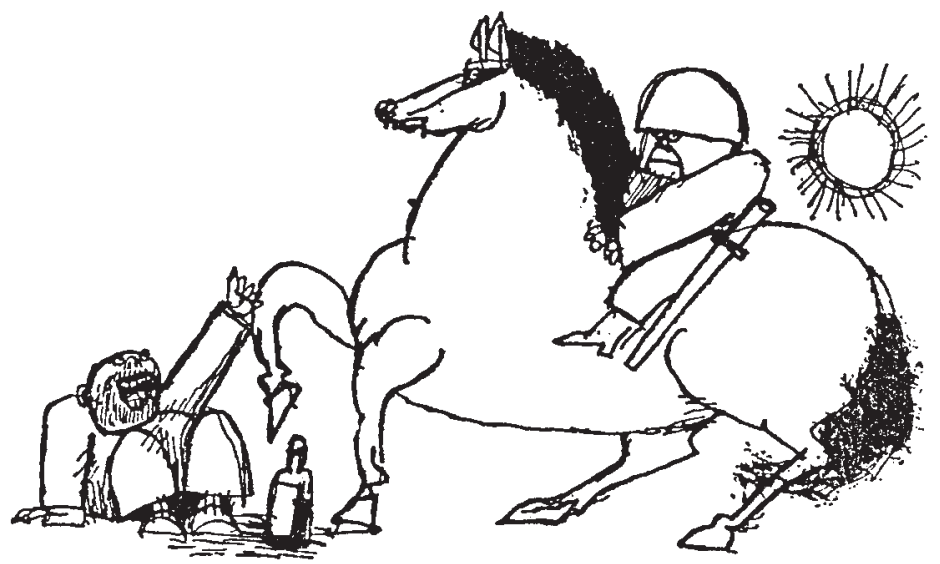

Ilustração de Jaguar para a crônica O Marechal e o Bêbado (Febeapá 2).

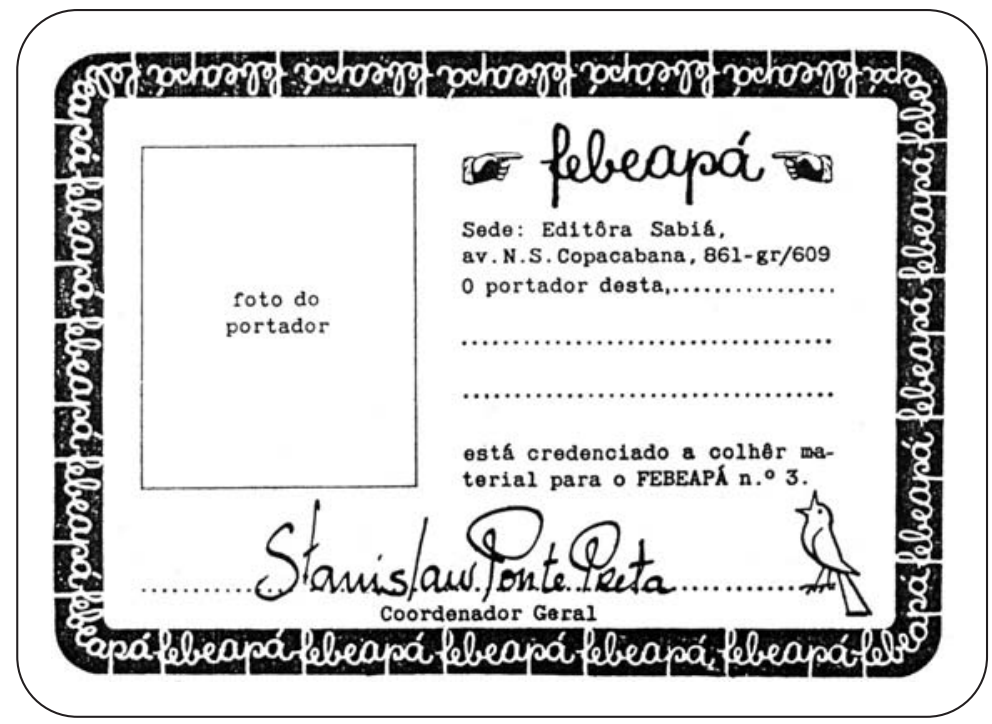

Carteirinha distribuída com a edição do Febeapá 2. 


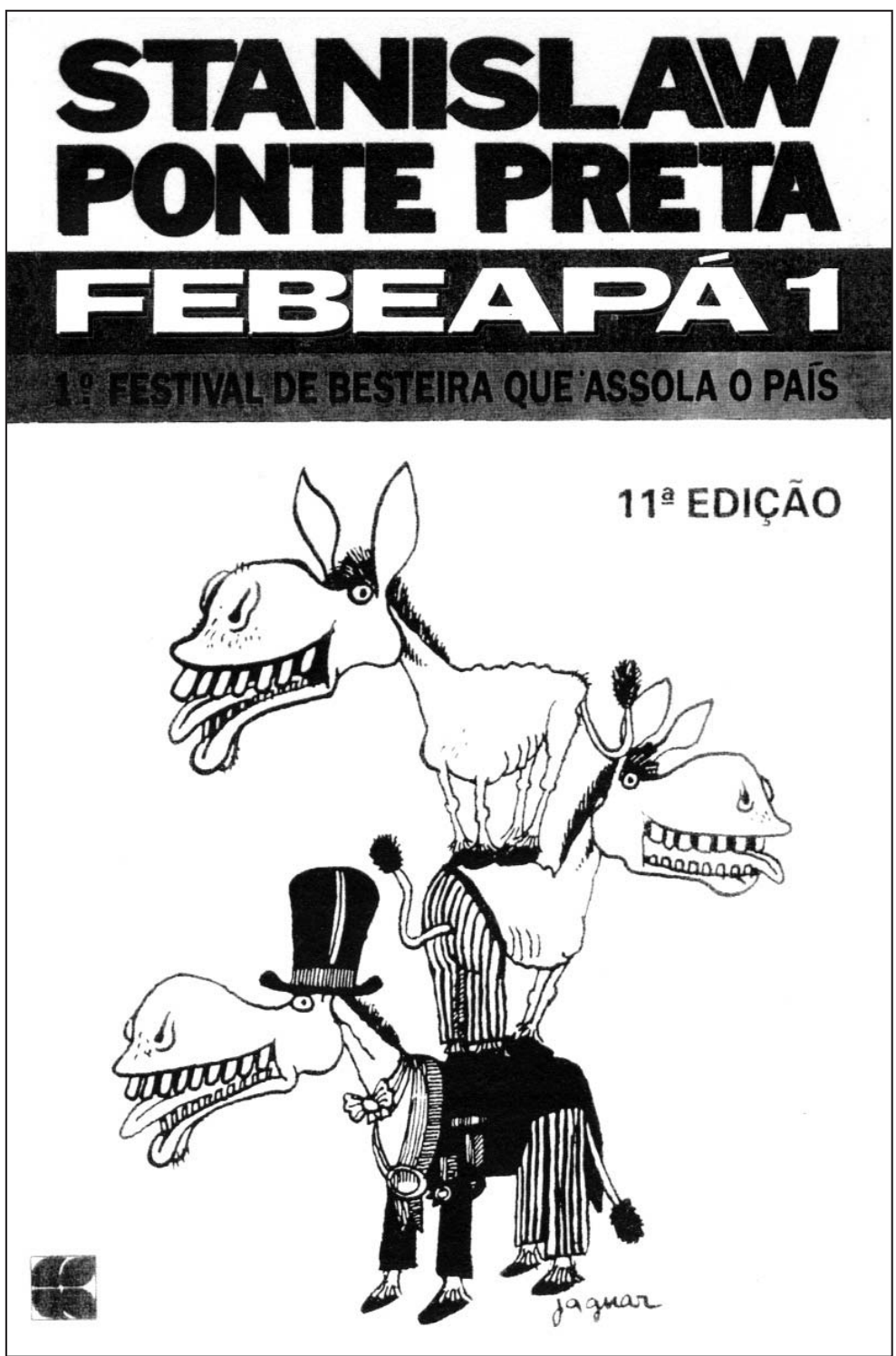

Capa do Febeapá 1. 11. ed. Rio de Janeiro: Civilização Brasileira, 1996. 


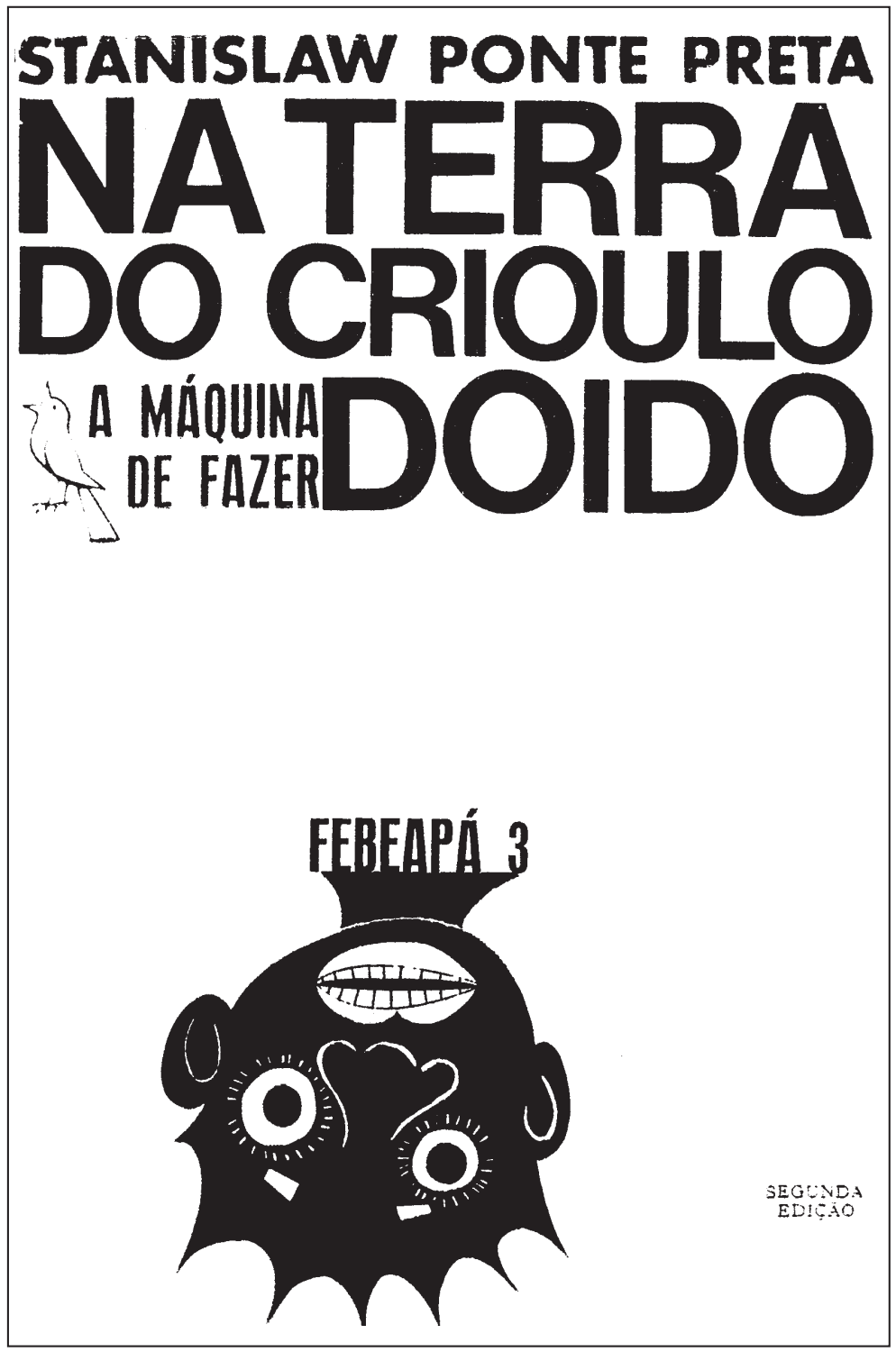

Capa do Febeapá 3. 2. ed. Rio de Janeiro: Editora Sabiá, 1968. 


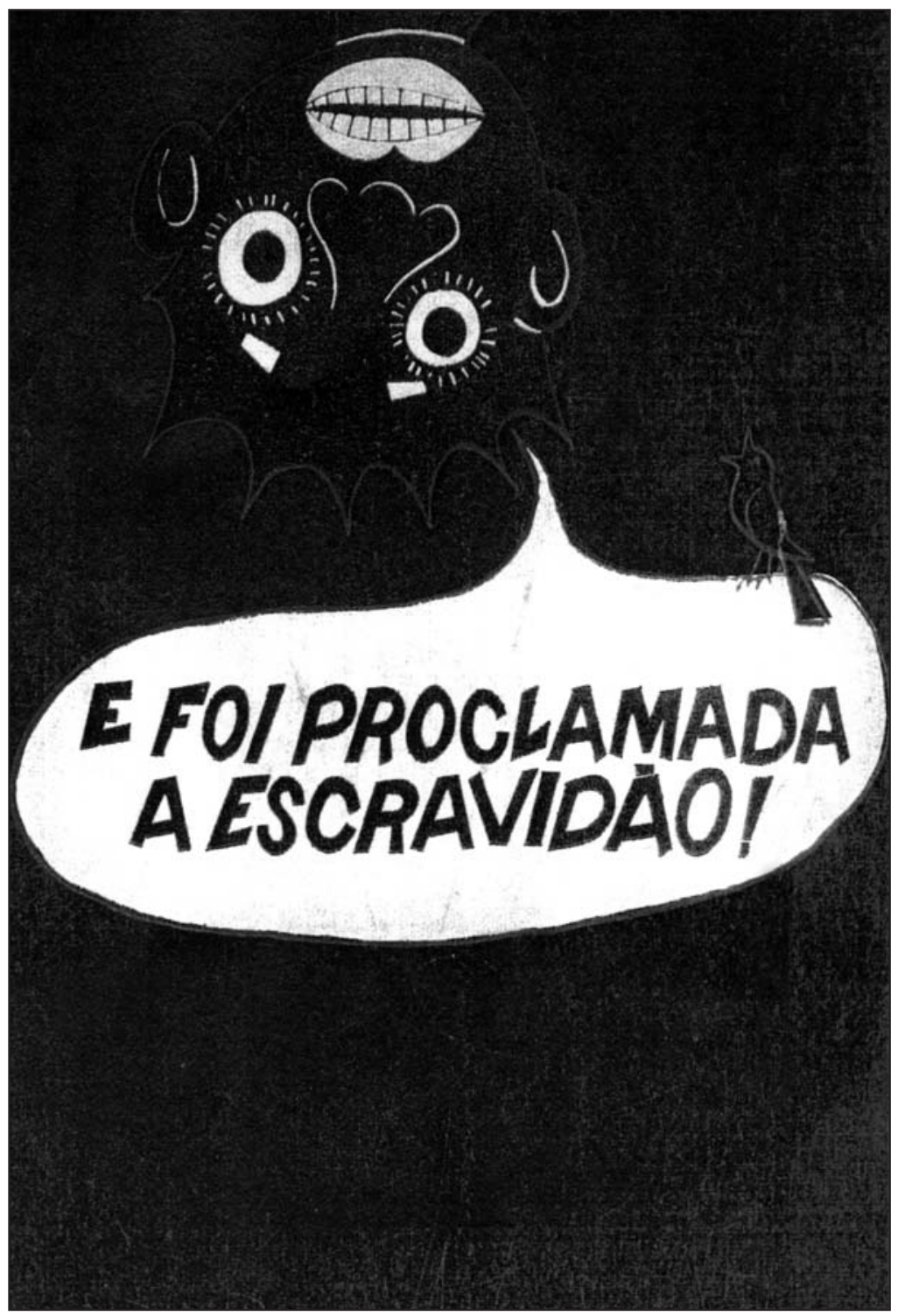

Contra-capa do Febeapá 3. Rio de Janeiro: Editora Sabiá, 1968. 


\section{NOTAS}

${ }^{1}$ Os livros consultados nesta pesquisa foram os seguintes: Tia Zulmira e eu. São Paulo: Círculo do Livro, s.d. (1.ed., 1961); Garoto linha dura. São Paulo: Círculo do Livro, s.d. (1.ed., 1964); Febeapá: o Primeiro Festival de Besteira que Assola o País. (capa e ilustrações de Jaguar). Rio de Janeiro: Ed. do Autor, 1966. (1.ed.); Febeapá 2: Segundo Festival de Besteira que assola o País. (ilustrações de Jaguar). Rio de Janeiro: Civilização Brasileira, 1993 (1.ed., 1967); Na terra do crioulo doido - A máquina de fazer doido - Febeapá 3. (capa de Maria Mynssen e ilustrações de Jaguar). Rio de Janeiro: Sabiá, 1968 (1.ed.).

${ }^{2}$ A análise dos personagens construídos por Sérgio Porto, assim como uma primeira abordagem do universo ficcional do autor, encontra-se em MORAES, D. Z. O trem tá atrasado ou já passou: sátira e as formas do cômico em Stanislaw Ponte Preta. São Paulo, 2003. Tese (Doutoramento) - FFLCH, Depto. de Letras Clássicas e Vernáculas, USP. Este ensaio é uma versão modificada dos capítulos I e III da tese. Quero deixar expresso o meu agradecimento pelas observações sempre muito pertinentes e iluminadoras da banca examinadora, formada pelos professores João Adolfo Hansen, Sandra Reimão, José Luiz Jobim, Zenir Campos Reis e Elias Tomé Saliba.

${ }^{3}$ Por exemplo, no Febeapá 2, Stanislaw cita Jaguar: "Quanto à perseguição a padres, vale transcrever a frase de Jaguar - ilustrador desta obra que o leitor tem em mãos: 'Um governo que começa organizando uma Arena, acaba perseguindo os cristãos.”' (p.78).

${ }^{4}$ CAMPOS, A. A Última Hora de Samuel; nos tempos de Wainer. Rio de Janeiro: ABI-Copim, 1993, p.54.

${ }^{5}$ Sobre a relevância dos estudos das representações sociais temos a seguinte argumentação: "Com efeito, para compreender a ordenação das sociedades humanas e para discernir as forças que as fazem evoluir, é importante dedicar igual atenção aos fenômenos mentais, cuja intervenção incontestavelmente é tão determinante quanto a dos fenômenos econômicos e demográficos. Pois não é em função de uma condição verdadeira, mas da imagem que constroem e que nunca fornece o reflexo fiel, que os homens pautam a sua conduta. Eles se esforçam para conciliá-la com os modelos de comportamento que são produto de uma cultura e que mais ou menos se ajustam, no decorrer da história, às realidades materiais". DUBY, G. História social e ideologia das sociedades. In: LE GOFF, J., NORA, P. (Org.) História: novos problemas. Rio de Janeiro: Francisco Alves, 1995, p.130-1.

${ }^{6}$ CHARTIER, R. A História Cultural: entre práticas e representações. Lisboa: Difel, Rio de Janeiro: Bertrand Brasil, 1990, p.17.

${ }^{7}$ POLLAK, M. Memória, Esquecimento, Silêncio. Estudos Históricos. Rio de Janeiro: Associação de Pesquisa e Documentação Histórica, v.2, n.3, 1989, p.4.

${ }^{8}$ Apud DINES, A. et al. Os idos de março e a queda de abril. Rio de Janeiro: Ed. José Álvaro, 1964, p.401.

${ }^{9}$ MONIZ, E. Golpe e Revolução. In: CONY, C. H. O Ato e o Fato: crônicas políticas. Rio de Janeiro: Civilização Brasileira, 1964, p.121. 
${ }^{10}$ FERNANDES, M. Pif-Paf, n.8, 27 ago. 1964, apud CORDOVANI, G. M. Millôr Fernandes, uma voz de resistência. São Paulo, 1997. Tese (Doutoramento) - FFLCH, Depto. de Letras Clássicas e Vernáculas, USP, p.130.

${ }^{11}$ O livro Febeapá 1 continha uma seleção de crônicas publicadas originalmente no jornal Última Hora, entre os anos de 1965 e 1966. Segundo o autor, durante o ano de 1967 o livro obteve muito sucesso, vendendo 37 mil exemplares.

${ }^{12}$ Particularmente o grupo político do governo, a ARENA - Aliança Renovadora Nacional usará desse artifício de comunicação. Stanislaw brinca com essa faceta lingüística do governo em nota do Febeapá 1: "E setembro começava com uma determinação do governador escalado Laudo Natel, criando um novo órgão, que tinha a sigla: SIRCFFSTETT. Ou seja, Setor de Investigações e Repressão ao Crime de Furtos de Fios de Serviços de Transmissões Elétricas, Telegráficas ou Telefônicas. Deve ser de lascar o cara trabalhar lá, atender o telefone e ter que dizer: aqui é da SIRCFFSTETT” (p.27).

${ }^{13}$ Cocoroca: 3. Diz-se de ou indivíduo quadrado, muito preso aos padrões tradicionais; 4. Diz-se de ou pessoa velha, caduca. (Dicionário Houaiss da Língua Portuguesa. Rio de Janeiro: Objetiva, 2001). Cocoroca: Sem importância. Em vernáculo, é um peixinho com muita espinha, que o pescador tem decepção quando pesca. Definição recolhida por Stanislaw para o texto "É esta a Gíria de Hoje". In: BANDEIRA, M., ANDRADE, C. D. de. (Ed.) Rio de Janeiro em prosa e verso. Rio de Janeiro: J. Olympio, 1965, p.370-9.

${ }^{14}$ MAGALHÃES, M. D. B. A lógica da suspeição: sobre os aparelhos repressivos à época da ditadura militar no Brasil. Revista Brasileira de História. São Paulo: ANPUH, Humanitas, FFLCH-USP, v.17, n.34, 1997, p.203-20. A pesquisadora, nesse texto, explica o processo de formação de uma rede de informantes para os órgãos de repressão.

${ }^{15}$ Para a análise literária do gênero cômico e suas derivações, a bufonaria e a sátira, estou utilizando os textos de BAKHTIN, M. A Cultura Popular na Idade Média e no Renascimento: o contexto de François Rabelais. São Paulo: Hucitec, Brasília: Ed. UnB, 1987; e Problemas da poética de Dostoiévski. Rio de Janeiro: Forense Universitária, 1997.

${ }^{16}$ A sátira de Stanislaw também atingiu o general-presidente Costa e Silva. Por exemplo na frase "a dupla caipira Costa e Silva", ou no texto sobre a inauguração da estrada de ferro de Brasília: "Na época, alguns derrubadores diziam que até de caminhão a locomotiva do primeiro trem para Brasília andou viajando. A composição era esperada na estação com banda e foguetório, que rompeu quando o trem apitou na curva e entrou de marcha à ré na estação. E por causa disso foi logo apelidado de trem Costa e Silva. Costa, porque entrou de marcha à ré e Silva, porque apitou na curva" (Febeapá 2, p.39).

${ }^{17}$ Brecht discutiu a questão de como produzir textos, em momentos de repressão política, que trouxessem a "verdade" aos leitores, sem tratar os assuntos com preconceitos, maniqueísmos ou tom de lamento. Para ele existem cinco condições para se escrever a "verdade": 1 . deve-se ter a coragem de dizer a verdade; 2 . deve-se ter inteligência para reconhecêla, pois ela está permanentemente disfarçada; 3 . deve-se ter a arte de manejá-la como uma arma; 4. deve-se ter a capacidade de escolher em que mãos será eficiente; 5 . deve-se ter a astúcia de divulgá-la. Os escritores devem escolher os temas com perspicácia, pensando 
nos efeitos que podem produzir na recepção e procurar um vínculo entre eles e os leitores. Mesmo em uma ditadura, o Estado não tem controle de tudo. BRECHT, B. Cinco maneiras de dizer a verdade. Revista Civilização Brasileira. São Paulo: Brasiliense, n.5/6, p.25973, mar. 1966.

${ }^{18}$ PINHEIRO, P. S. Autoritarismo e transição. Revista USP. São Paulo: Universidade São Paulo, Coordenadoria de Comunicação Social, v.9, mar-maio 1991, p.56.

${ }^{19}$ OLIVEIRA, E. R. de. As forças Armadas: política e ideologia no Brasil (1964-1969). Rio de Janeiro: Vozes, 1976. Apud Nosso Século: memória fotográfica do século 20. São Paulo: Abril Cultural, 1980, v.5, p.161.

${ }^{20}$ KUCINSKI, B. Jornalistas e Revolucionários: nos tempos da imprensa alternativa. São Paulo: Página Aberta, 1991, p.23-4.

${ }^{21}$ No anexo apresentamos uma série de caricaturas que exemplificam a visão do humorismo sobre os militares.

${ }^{22}$ O conto foi publicado na Revista Pif-Paf, n.2, jun. 1964. Análise literária feita por CORDOVANI, G. M. Millôr Fernandes, uma voz de resistência, op. cit., p.100-8.

${ }^{23}$ CÃO, CAVALO. In: Dicionário Houaiss, op. cit.

${ }^{24}$ A nota refere-se ao Marechal Presidente Costa e Silva. Pretende-se um contraponto ao discurso do poder instituído. Costa e Silva na posse afirmava: "Preparar os homens de amanhã para uma democracia autenticamente nossa”. Apud Nosso Século: memória fotográfica do Brasil no século 20, op. cit., p.125.

${ }^{25}$ A frase refere-se ao Marechal Presidente Castelo Branco, morto em um desastre de avião em 18 de julho de 1967. A Constituição de 1967 foi sancionada sob pressão dos militares e consolidava algumas medidas autoritárias tomadas pela ditadura após o golpe.

${ }^{26}$ MARECHAL. In: Dicionário Houaiss da Língua Portuguesa, op. cit.

${ }^{27}$ Informações extraídas de Nosso Século: memória fotográfica do Brasil no século 20, op. cit., v.2: 1910-1930, p.25-9.

${ }^{28} \mathrm{O}$ uso de metonímias, isto é, tomar partes da imagem idealizada para ressaltar vícios, é uma técnica do gênero do ridículo. A imagem é decomposta em partes, que, por sua vez, são deformadas segundo um estereótipo negativo compreendido pela recepção. Trata-se de conhecer o repertório das deformidades físicas e morais que são consideradas ridículas para efetuar-se o discurso satírico. Assim, desenhar o militar com patas de cavalo é atribuir ao militar as características negativas associadas à imagem do animal. Além disso a deformidade é uma monstruosidade por princípio e causa repugnância à platéia. $\mathrm{O}$ riso é o sinal do entendimento da incongruência entre qualidades afirmadas (inteligência, ética, confiança, proteção) e vícios manifestados (ignorância, imoralidade, desonestidade, violência). Segundo Tesauro, as deformidades físicas e morais que produzem o ridículo são as seguintes: o sujo, o pequeno, o mutilado, o obsceno, o degradado, o maculado, o estropiado, o sórdido, o vil. TESAURO, E. Tratado dos ridículos. Campinas: Unicamp, Instituto da Linguagem, CEDAE, 1992 (Série: Referências), p.33-6. 
${ }^{29}$ O sistema político autoritário implantado em 1964 passou por várias fases, mostrando um dinamismo muito grande. O processo de ações e reações dentro da corporação militar e na sociedade civil deu uma configuração diferente a cada momento histórico. Segundo Maria Helena Moreira Alves: “A coalizão no poder não dispunha de um modelo para todas as estruturas do novo Estado; contava apenas com uma elaborada doutrina, ou ideologia, em que se baseava seu pensamento político. Os interesses econômicos da aliança de classes que apoiou o golpe combinaram-se a elementos desta doutrina para impor ao Estado um caráter autoritário. Mas a efetiva edificação do Estado de Segurança Nacional resultou de um confronto dialético com a oposição. Foi um processo contínuo de reformulação de planos e normas e de expansão da abrangência do poder coercitivo". ALVES, M. H. M. Estado e oposição no Brasil (1964-1984). Petrópolis: Vozes, 1984, p.52-3.

30 "Memória: fenômeno individual e psicológico, a memória liga-se também à vida social e é objeto da atenção do Estado que, para conservar os traços de qualquer acontecimento do passado, produz diversos tipos de 'documento/monumento', faz escrever a história, acumular objetos . A apreensão da memória depende deste modo do ambiente social e político: trata-se da aquisição de regras de retórica e também da posse de imagens e textos que falam do passado, em suma, de um certo modo de apropriação do tempo...”. LE GOFF, J. História e memória. Campinas: Ed. Unicamp, 1994, p.483.

${ }^{31}$ A alegoria, como recurso artístico, designa diretamente um sentido que se quer transmitir. Depende da intelecção do receptor, que deve conhecer o código de leitura preestabelecido. A relação entre significante e significado está previamente estabelecida, portanto, a alegoria é uma linguagem arbitrária, convencional, imotivada, pois representa conceitos. Opera fortuitamente com sinais visíveis. Deve transmitir o sentido do signo antes de sabermos o que significa. O símbolo, por outro lado, designa indiretamente um sentido que se quer transmitir, acolhe a percepção do receptor e, só posteriormente, exige a intelecção. Permite uma maior liberdade de interpretação. O símbolo é sensorial e a alegoria é racional. Todorov, tratando da distinção moderna entre símbolo e alegoria, diz que: "o símbolo tem a grande vantagem de ser capaz de apresentar tudo como uma presença sensível, pois encerra toda a idéia em um ponto de manifestação ... Mas a alegoria tem vantagens infinitas para um pensamento mais profundo. Ela pode perceber o objeto real como puro pensamento, sem o perder como objeto". TODOROV, T. Teorias do símbolo. Lisboa: Ed. 70, 1979, p.74.

${ }^{32}$ LE GOFF, J. História e memória, op. cit., p.535-6.

${ }^{33}$ Até 1963, Stanislaw organizava os livros com seleções de crônicas relacionadas a cada personagem criado por ele. Os títulos dos livros destacavam essas personagens: Tia Zulmira e eu (1961), Primo Altamirando e elas (1962), Rosamundo e os outros (1963). Já em 1964, Stanislaw resolve mudar a orientação de publicação de seus livros e abandona a prática de sublinhar nos títulos as personagens. Resolve escolher como denominação do livro o título de uma crônica que metaforizava o ambiente político e cultural do período: Garoto linha dura. No prefácio o autor primeiramente desconversa ao explicar o significado desta escolha, dizendo que está copiando a "fórmula clássica entre os cronistas que - ao publicarem seleções de crônicas — limitam-se a botar no título o nome da primeira crônica". 
No entanto, imediatamente após fornecer essa justificativa, que parece ser neutra, Stanislaw aponta a sua real intenção. É uma linguagem dissimulada.

${ }^{34}$ ALVES, M. H. M. Estado e oposição no Brasil (1964-1984), op. cit., p.57-8.

${ }^{35}$ No ano de 1965, por exemplo, a censura proibiu, no Rio de Janeiro, as peças O berço do herói, de Dias Gomes; Brasil pede passagem, show com texto de Castro Alves e Sérgio Porto; Berço esplêndido, de Sérgio Porto, além de três peças estrangeiras de Górki, Brecht e Feydeau. A peça Liberdade, liberdade, de Flávio Rangel é uma das poucas liberadas. Stanislaw vai citar o fato com grande entusiasmo, tomando o nome da peça como título de uma de suas crônicas do Febeapá 1 ("Cronologia”. In: Nosso século: memória fotográfica do Brasil no século 20, op. cit., v.5, p.IX.

${ }^{36}$ Cel. Ney Aminthas de Barros Braga: Governador do Estado do Paraná entre 1961 e 1965, Ministro da Agricultura entre 1965 e 1966 e Ministro da Educação e Cultura entre 1974 e 1978.

${ }^{37}$ A SUMOC - Superintendência da Moeda e do Crédito era o órgão controlador da oferta de moeda. Desde o governo de Café Filho (1954) vinha aplicando um forte esquema de contenção da inflação por meio da restrição do crédito e controle dos gastos públicos. Exigia dos bancos que a metade dos depósitos fosse recolhida para os cofres públicos. Em 1964 foi aprovado um projeto que transformava a SUMOC em Banco Central. Cf. MARANHÃO, R. O Governo Juscelino Kubitschek. São Paulo: Brasiliense, 1981, p.50-4.

${ }^{38}$ Tenório Cavalcante de Albuquerque, filiado à UDN, era deputado federal pelo Rio de Janeiro. Alagoano, obteve sua fama por levar um Colt 38 folheado a ouro, a inseparável "Lourdinha”, embaixo de uma capa preta. Sua carreira política começou como vereador por Caxias, na Baixada Fluminense. Foi ferido várias vezes em brigas com políticos e com a polícia. Era amigo de marginais. Tornou-se uma figura muito conhecida e o humorista Carlos Estevão chamava-o de "Jack Palance de Caxias City". Foi adversário político de Getúlio Vargas. Cf. Nosso Século: memória fotográfica do século 20, op. cit., v.4, p.137.

${ }^{39}$ Podemos perceber a intertextualidade no conto "A Igreja do Diabo", de Machado de Assis, e na crônica "Eu e Bebu na Hora Neutra da Madrugada", de Rubem Braga. Machado de Assis usa o artifício do espaço deslocado da realidade para refletir sobre a natureza humana. Rubem Braga, no entanto, faz Belzebu falar a linguagem da política. Está refletindo sobre a essência das revoluções e propõe que elas não passam de uma disputa pelo poder. A crônica de Rubem Braga é de 1942 e foi revista em 1948. Trata-se do fim do Estado Novo e a crônica revela uma desilusão com as correntes políticas. A crônica de Stanislaw, por sua vez, trata dos pequenos poderes, da corrupção cotidiana e manifesta desilusão com a capacidade de o Estado Brasileiro se constituir como um Estado de direito. (ASSIS, M. de. "A Igreja do Diabo". In. Histórias sem data. Rio de Janeiro: Jackson, 1957, e BRAGA, R. "Eu e Bebu na Hora Neutra da Madrugada”. In: 200 crônicas escolhidas. Rio de Janeiro: Record, 1993.)

${ }^{40}$ Sobre as tendências políticas do período consultar HOLLANDA, H. B. de, GONÇALVES, M. A. Cultura e participação política nos anos 60. São Paulo: Brasiliense, 1984, e TOLEDO, C. N. O governo Goulart e o golpe de 64. São Paulo: Brasiliense, 1982. 
${ }^{41}$ Stanislaw busca a verossimilhança, apresentando sempre as histórias como tendo sido recolhidas de jornais da época.

${ }^{42} \mathrm{O}$ riso forte está associado às formas cômicas populares — bufonaria, jocosidade, ridicularização de pessoas e comportamentos - que produzem a gargalhada. No riso forte não haveria identificação entre os personagens e aquele que ri. Não há propriamente reflexão, pois o certo e o errado, a regra, estão introjetados na recepção. Estas formas cômicas populares visam corrigir a falha e repor a norma, adaptar o indivíduo à sociedade. É dessa forma que é concebido o estudo sobre o riso em Bergson. O riso fraco, por sua vez, é uma expressão que busca dar conta da natureza do "humor", que produz, no máximo, um sorriso entre dentes. Do ponto de vista do conteúdo, com o humor se está fazendo uma "crítica consciente e explícita das regras". O humorista não está censurando pessoas ou comportamentos e sim mostrando as incongruências, as contradições, a distância entre o ser e a aparência, as fissuras culturais. O humor é cético, é pessimista, é humanista. Esse é o ponto de vista de Umberto Eco: "Se o exemplo do cômico era uma velha caduca que se enfeitava toda como uma adolescente, o humorismo impunha que se perguntasse também por que agia desta maneira. Nesse momento eu já não me sinto superior e distante em relação à personagem animalesca que age contra as boas regras, mas começo a identificar-me com ela, sofro seu drama e minha risada se transforma em sorriso". ECO, U. O cômico e a Regra. In: Viagem na irrealidade cotidiana. Rio de Janeiro: Nova Fronteira, 1984, p.350. De todo modo, não é conveniente partir de definições gerais quando se trata da analisar a literatura cômica. O entendimento dos procedimentos cômicos depende do conhecimento do ambiente histórico-literário e dos contextos de enunciação específicos. No entanto, as expressões "riso forte" e "riso fraco" são metáforas poderosas para expressar as múltiplas tonalidades dos discursos cômicos. Tanto é assim que Bergson, Freud e Pirandello discutem a diferença entre o cômico e o humor, para compreender a variação dos efeitos literários. (Cf. BERGSON, H. O riso: ensaio sobre o significado do cômico. Lisboa: Guimarães, 1993; FREUD, S. Os chistes e sua relação com o inconsciente. Rio de Janeiro: Imago, 1996; PIRANDELLO, L. O humorismo. São Paulo: Experimento, 1996.)

${ }^{43}$ Para uma análise do significado do riso nas primeiras décadas republicanas ver o ensaio de SALIBA, E. T. A dimensão cômica da vida privada na República. In. SEVCENKO, N. (Org.) História da vida privada no Brasil. República: da Belle Époque à Era do Rádio. São Paulo: Companhia das Letras, 1998.

${ }^{44}$ NORA, P. (Dir.) Les Lieux de mémoire. Paris: Gallimard, 1984, p.XVII-XLII.

Artigo recebido em 3/2004. Aprovado em 5/2004 